\title{
PRAWNOUSTROJOWY STATUS SIŁ ZBROJNYCH W KONSTYTUCJI RZECZYPOSPOLITEJ POLSKIEJ
}

\section{WPROWADZENIE}

We współczesnym świecie rola siły zbrojnych uległa znacznemu rozszerzeniu. Armia nie służy już tylko do obrony państwa, ale również stała się istotnym elementem polityki zagranicznej m.in. w aspekcie odstraszania i wywierania nacisku politycznego ${ }^{1}$. Jednocześnie ewolucja zagrożeń w środowisku bezpieczeństwa (zwłaszcza transformacja współczesnego wymiaru terroryzmu) sprawiła, że siły zbrojne są coraz częściej używane do pomocy innym służbom mundurowym i organom cywilnym w zapewnienie bezpieczeństwa wewnętrznego ${ }^{2}$.

Dr Mariusz Antoni KamiŃSKI - dyrektor Szkoły Administracji Obronnej, Akademia Sztuki Wojennej, adiunkt w Katedrze Powszechnej Obrony Narodowej, Wydział Bezpieczeństwa Narodowego, Akademia Sztuki Wojennej, Al. gen. A. Chruściela „Montera” 103, 00-910 Warszawa-Rembertów; e-mail: m.kaminski@akademia.mil.pl; https://orcid.org/0000-0001-9395-9744

${ }^{1}$ B. Balcerowicz bardzo trafnie skonstatował, że kluczem do zrozumienia miejsca i roli sił zbrojnych jest właściwe rozpoznanie i zrozumienie relacji, jakie zachodzą między polityką i jej narzędziami. Jego zdaniem polityka do osiągnięcia swoich celów posługuje się określonymi środkami, z których trzy należy uznać za najważniejsze: środki dyplomatyczne, środki ekonomiczne oraz środki militarne. Ponadto wskazuje, że rola i znaczenie siły militarnej w polityce (szczególnie w polityce zagranicznej), są różne w różnych stanach funkcjonowania państwa: pokoju, kryzysu i wojny. B. Balcerowicz, Sity zbrojne w stanie pokoju, kryzysu, wojny, Warszawa: Wydawnictwo Naukowe Scholar 2010, s. 28-29.

${ }^{2}$ Więcej na temat wewnętrznej funkcji Sił Zbrojnych RP zob. W. KiTLER, Rola sił zbrojnych w państwie, [w:] Prawo wojskowe, red. W. Kitler, D. Nowak, M. Stepnowska, Warszawa: Woltes Kluwer 2017, s. 27-45; B. PACEK, Udział Sił Zbrojnych RP w bezpieczeństwie wewnętrznym państwa, Warszawa: Wydawnictwo Akademii Obrony Narodowej 2013; G. Sobolewski, Sity Zbrojne RP w zarządzaniu kryzysowym. Aspekt narodowy i międzynarodowy, Warszawa: Wydawnictwo Akademii Obrony Narodowej 2013. 
Definicja „sił zbrojnych” nie występuje ani w Konstytucji, ani w ustawodawstwie zwykłym. Natomiast możemy ją odnaleźć w literaturze przedmiotu zarówno z zakresu nauki o bezpieczeństw, jak i nauk prawnych. W Stowniku terminów z zakresu bezpieczeństwa narodowego siły zbrojne zdefiniowano jako wyspecjalizowany organ państwa, przeznaczony do ochrony i obrony jego interesów przez wykorzystanie go jako czynnika odstraszania przed agresją lub - w razie konieczności - prowadzenia walki zbrojnej aż do osiągnięcia założonego celu politycznego. Z punktu widzenia struktur organizacyjnych można je podzielić na regularne i nieregularne siły zbrojne, a z punktu widzenia charakteru prowadzonych działań na wojska operacyjne oraz siły i środki obrony terytorialnej, zaś ze względu na środowisko, w którym prowadzą działania na wojska lądowe, siły powietrzne i marynarkę wojennąa ${ }^{3}$.

Siły zbrojne są istotnym narzędziem w realizacji zasadniczych celów państwa, a jednocześnie posiadają ogromny potencjał militarny (ze względu na uzbrojenie, sprzęt, wyszkolenie żołnierzy i inne). Dlatego też w demokratycznym państwie prawnym kluczowym elementem jest właściwe uregulowanie zasad funkcjonowania sił zbrojnych w tym zwłaszcza cywilnej kontroli nad ich działalnością. Regulacje prawne dotyczące tej materii określa się mianem prawa wojskowego. W definicji zaproponowanej przez W. Kitlera prawo wojskowe to „zespół norm prawnych regulujących podstawy i zasady funkcjonowania sił zbrojnych, żołnierzy i personelu cywilnego oraz stosunki zachodzące między nimi a innymi podmiotami krajowymi i międzynarodowymi, a także zbiór przepisów szczególnych dotyczących sił zbrojnych w okresie stanów nadzwyczajnych, głównie stanu wojennego (i w czasie wojny), prawa karnego i przepisów dyscyplinarnych w wojsku"4. W Polsce na rozbudowany system prawa wojskowego składają się akty normatywne różnej rangi (przede wszystkim ustawowej).

Fundamentem prawa wojskowego są rozwiązania konstytucyjne. W polskiej ustawie zasadniczej z 2 kwietnia 1997 r. status Siły Zbrojne Rzeczypospolitej Polskiej [dalej cyt.: „Siły Zbrojne RP”] unormowano przede wszystkim w art. 26, który stanowi, że Siły Zbrojne RP służą ochronie niepodległości państwa i niepodzielności jego terytorium oraz zapewnieniu bezpieczeństwa i nienaruszalności jego granic, a także zachowują neutralność w sprawach politycznych oraz podlegają cywilnej i demokratycznej kontroli ${ }^{5}$. Jednak rozwiązania konstytucyjne

${ }^{3}$ Stownik terminów z zakresu bezpieczeństwa narodowego, red. J. Kaczmarek, W. Łepkowski, B. Zdrodowski, Warszawa: Wydawnictwo Akademii Obrony Narodowej 2008, s. 121.

${ }^{4}$ W. KITLER, Organizacja bezpieczeństwa narodowego RP. Aspekty ustrojowe, prawno-administracyjne i systemowe, Toruń: Wydawnictwo Adam Marszałek 2018, s. 168.

${ }^{5}$ Konstytucja Rzeczypospolitej Polskiej z dnia 2 kwietnia 1997 r., Dz. U. Nr 78, poz. 483 z późn. zm., art. 26. 
określające status Sił Zbrojnych RP powinny być rozpatrywane w dużo szerszym kontekście związanym z obronnością i bezpieczeństwem narodowym (w których zasadniczą rolę odgrywają Siły Zbrojne RP).

Celem mojej publikacji uczyniłem prawnoustrojowy statusu Sił Zbrojnych w Konstytucji RP w tym m.in. ich rolę w realizacji głównych celów państwa polskiego, relacje do innych zasad ustrojowych oraz obywatelskiego obowiązku obrony Ojczyzny, służby wojskowej w kontekście praw i wolności obywatelskich, a także konstytucyjnych kompetencji naczelnych organów państwa (w tym w zakresie cywilnej i demokratycznej kontroli nad Siłami Zbrojnymi). Porównuję również przepisy z polskiej ustawy zasadniczej z rozwiązaniami konstytucyjnymi wybranych państw członkowskich Sojuszu Północnoatlantyckiego. Badania służą weryfikacji hipotezy roboczej, która brzmi: na prawnoustrojowy status Sił Zbrojnych RP w Konstytucji składają się przepisy rozproszone w różnych rozdziałach ustawy zasadniczej, które rozpatrywane wspólnie i w powiązaniu ze sobą, tworzą dość spójny i rozbudowany katalog, który zasadniczo jest zbliżony do rozwiązań konstytucyjnych innych państw członkowskich NATO.

Ze względu na fakt, iż zagadnienia $\mathrm{z}$ zakresu bezpieczeństwa narodowego (do których z całą pewnością należy status Sił Zbrojnych RP) mają interdyscyplinarny charakter, to $\mathrm{w}$ moich badaniach wykorzystałem zarówno analizę literatury przedmiotu z zakresu nauk prawnych, jak też nauki o bezpieczeństwie (która jest w Polsce ciągle młodą dyscypliną naukową ${ }^{6}$ ). Ponadto w analizie uwzględniłem bogate orzecznictwo Trybunału Konstytucyjnego. Zastosowałem również metodę historyczno-porównawczą badając przepisy dotyczące sił zbrojnych w polskich ustawach zasadniczych oraz metodę prawno-porównawczą analizując rozwiązania konstytucyjne dotyczące sił zbrojnych w państwach członkowskich Sojuszu Północnoatlantyckiego.

Przy wyborze państw do analizy prawno-porównawczej starałem się ukazać jak najszersze spektrum omawianych zagadnień. Dlatego z pośród 29 państw członkowskich NATO uwzględniłem państwa Europy kontynentalnej, zróżnicowane pod względem położenia geopolitycznego, uwarunkowań historycznych,

\footnotetext{
${ }^{6}$ Nauki o bezpieczeństwie utworzono jako nową dyscyplinę naukową w dziedzinie nauk społecznych uchwałą Centralnej Komisji do Spraw Stopni i Tytułów z dnia 28 stycznia 2011 r. zmieniającą uchwałę w sprawie określenia dziedzin nauki i dziedzin sztuki oraz dyscyplin naukowych i artystycznych, M. P. Nr 14, poz. 149. Natomiast na podstawie rozporządzania Ministra Nauki i Szkolnictwa Wyższego z dnia 20 września 2018 r. w sprawie dziedzin nauki i dyscyplin naukowych oraz dyscyplin artystycznych, Dz. U. poz. 1818, połączono nauki o bezpieczeństwie z naukami o obronności tworząc jedną dyscyplinę naukową.
} 
rozwiązań prawnych, kultury wojskowej ${ }^{7}$ oraz modelu służby wojskowej (system armii zawodowej lub armii z poboru). Tak więc do analizy wybrałem:

- dwa państwa Europy Zachodniej (Niemcy, Francja);

- dwa państwa Europy Południowej, które przeszły w latach 80-tych XX w. przemiany z ustrojów autorytarnych do demokracji (Hiszpania, Grecja);

- dwa państwa nordyckie (Dania, Norwegia);

- dwa postkomunistyczne państwa Europy Środkowo-Wschodniej (Czechy, Estonia).

\section{ASPEKTY HISTORYCZNE}

Przepisy konstytucyjne dotyczące Sił Zbrojnych i obywatelskiego obowiązku obrony Ojczyzny mają w Polsce bogatą tradycję. Już w Ustawie Rządowej z 3 maja $1791 \mathrm{r}$. w rozdziale XI „Sił zbrojna narodowa” wprowadzono przepis zgodnie z którym ,[...] Wojsko nic innego nie jest, tylko wyciągnięta siła obronna i porządna $z$ ogólnej siły narodu. Naród winien wojsku swemu nadgrodę i poważanie za to, iż się poświęca jedynie dla jego obrony. Wojsko winno narodowi strzeżenia granic i spokojności powszechnej, słowem winno być jego najsilniejszą tarczą. Aby przeznaczenia tego dopełniło niemylnie, powinno zostawać ciągle pod posłuszeństwem władzy wykonawczej, stosownie do opisów prawa, powinno wykonać przysięgę na wierność narodowi i królowi i na obronę konstytucji narodowej. Użytem być więc wojsko narodowe może na ogólną kraju obronę, na strzeżenie fortec i granic, lub na pomoc prawu, gdyby kto egzekucji jego nie był posłusznym"

Przepisy dotyczące Sił Zbrojnych znalazły się również w konstytucjach z okresu rozbiorów - Ustawie Konstytucyjnej Księstwa Warszawskiego z 22 lipca 1807 r. (art.79-81) $)^{9}$ i Ustawie Konstytucyjnej Królestwa Polskiego z 27 listopada 1815 r. $(\operatorname{art} .153-156)^{10}$.

${ }^{7}$ Zob. więcej na temat kultury wojskowej: H. MöLDER, The Development of Military Cultures, [w:] Apprenticeship, Partnership, Membership: Twenty Years of Defence Development in the Baltic States, red. T. Lawrence, T. Jermalavičius, Tallinn: International Center for Defence Studies 2013 , s. $85-121$.

${ }^{8}$ Ustawa Rządowa z 3 maja 1791 r., [w:] Konstytucje w Polsce: 1791-1990, wyb. i oprac. T. Kołodziejczyk, M. Pomianowska, Warszawa: Wydawnictwo Przemiany 1990, s. 13-18.

${ }^{9}$ Ustawa Konstytucyjna Księstwa Warszawskiego z dnia 22 lipca 1807 r., [w:] Konstytucje w Polsce: 1791-1990, s. 37-43.

${ }^{10}$ Ustawa Konstytucyjna Królestwa Polskiego z dnia 27 listopada 1815 r., [w:] Konstytucje w Polsce: 1791-1990, s. 48-57. 
W okresie międzywojennym w Konstytucji z 17 marca 1921 r. w art. 91 ustanowiono, że „Wszyscy obywatele są obowiązani do służby wojskowej. Rodzaj i sposób, porządek i czas trwania służby, zwolnienie od tego obowiązku oraz wszelkie świadczenia na cele wojskowe będą określone w drodze ustawodawczej”. Natomiast w art. 122 wskazano, że postanowienia o prawach obywatelskich stosują się także do osób należących do siły zbrojnej, a wyjątki od tej zasady określają osobne ustawy wojskowe, zaś art. 123 normował, że „Siła zbrojna może być użyta tylko na żądanie władzy cywilnej przy ścisłem zachowaniu ustaw do uśmierzenia rozruchów lub do przymusowego wykonania przypisów prawnych. Wyjątki od tej zasady dopuszczalne są tylko na mocy ustaw o stanie wyjątkowym i wojennym" "11.

Z kolei w Konstytucji z 23 kwietnia 1935 r. w art. 3 podkreślono, że Siły Zbrojne pozostają pod zwierzchnictwem Prezydenta RP, a ich zadaniem naczelnym jest służenie Rzeczypospolitej. Przepisy te rozwinięto w rozdziale VIII zatytułowanym „Siły Zbrojne”, gdzie w art. 61 wskazano, że Siły Zbrojne stoją na straży bezpieczeństwa i praw zwierzchniczych Rzeczypospolitej, a wszyscy obywatele są obowiązani do służby wojskowej i świadczeń na rzecz obrony Państwa. Natomiast w art. 63, ustanowiono, że Prezydent jako Zwierzchnik Sił Zbrojnych postanawia o ich użyciu do obrony Państwa oraz „wydaje dekrety w zakresie zwierzchnictwa Sił Zbrojnych, a w szczególności określi dekretem organizację naczelnych władz wojskowych, oznaczając w nim sposób kontrasygnowania aktów". W przypadku mianowania Naczelnego Wodza (który za akty związane z dowództwem, odpowiadał przed Prezydentem) prawo dysponowania Siłami Zbrojnymi przechodziło na niego ${ }^{12}$.

W Konstytucji Polskiej Rzeczypospolitej Ludowej z 22 lipca 1952 r. regulacje dotyczące Sił Zbrojnych znalazły się w pierwszym rozdziale dotyczącym ustroju politycznego. Zgodnie z art. 6 „Siły zbrojne Polskiej Rzeczypospolitej Ludowej stoją na straży suwerenności i niepodległości Narodu Polskiego, jego bezpieczeństwa i pokoju". Z kolei w na podstawie art. 78 obrona Ojczyzny jest najświętszym obowiązkiem każdego obywatela, zaś służba wojskowa jest zaszczytnym obowiązkiem patriotycznym obywateli Polskiej Rzeczypospolitej Ludowej. Jednocześnie w art. 79 ust. 1 zaakcentowano, że „czujność wobec wrogów narodu oraz pilne strzeżenie tajemnicy państwowej jest obowiązkiem każdego obywatela PRL" zaś w ust. 2 dodano ,zdrada Ojczyzny: szpiegostwo, osłabianie sił zbrojnych, przejście na stronę wroga - karana jest $\mathrm{z}$ całą surowością prawa jako najcięższa zbrodnia"13.

${ }^{11}$ Ustawa z dnia 17 marca 1921 r. Konstytucja Rzeczypospolitej Polskiej, Dz. U. Nr 44, poz. 267 i Nr 52, poz. 334.

${ }^{12}$ Ustawa konstytucyjna z dnia 23 kwietnia 1935 r., Dz. U. Nr 30, poz. 227.

${ }^{13}$ Konstytucja Polskiej Rzeczypospolitej Ludowej z dnia 22 lipca 1952 r., Dz. U. Nr 33, poz. 232. 


\section{KONSTYTUCYJNE I USTAWOWE REGULACJE PRAWNE DOTYCZĄCE SIŁ ZBROJNYCH RP}

O istotnym znaczeniu Sił Zbrojnych RP świadczy fakt, że ustawodawca zawarł przepisy dotyczące ich roli $\mathrm{w}$ państwie w pierwszym rozdziale Konstytucji RP z 2 kwietnia 1997 r. wśród głównych zasad ustrojowych. Artykuł 26 ust. 1 ustawy zasadniczej wskazuje, że „Siły Zbrojne Rzeczypospolitej Polskiej służą ochronie niepodległości państwa i niepodzielności jego terytorium oraz zapewnieniu bezpieczeństwa i nienaruszalności jego granic". Przepis ten jest spójny z regulacjami art. 5 Konstytucji, zgodnie z którym Rzeczpospolita Polska strzeże niepodległości i nienaruszalności swojego terytorium, zapewnia wolności i prawa człowieka i obywatela oraz bezpieczeństwo obywateli, strzeże dziedzictwa narodowego oraz zapewnia ochronę środowiska, kierując się zasadą zrównoważonego rozwoju. Są to podstawowe cele państwa polskiego, wśród których wymienione jako pierwsze zadanie „strzeżenia niepodległość” stanowi naturalną i podstawą funkcją państwa. Niepodległość jest bowiem wartością najwyższą. Nawiązanie do walki o niepodległość i historycznych doświadczeń Narodu Polskiego znajduje się również w preambule ustawy zasadniczej: „[...] wdzięczni naszym przodkom za ich pracę, za walkę o niepodległość okupioną ogromnymi ofiarami [...]"14. Z kolei zadanie strzeżenia „nienaruszalności granic” podkreśla znaczenie terytorium jako jednego z głównych atrybutów definiujących państwo (obok ludności oraz suwerennej władzy politycznej). Ponadto na państwie polskim (a konkretnie na jego organach) spoczywa także zadanie zapewnienie bezpieczeństwa swoim obywatelom. Jak podkreśla M. Florczak-Wątor pojęcie to należy rozumieć szeroko ,jjako stan dający poczucie pewności i stabilności oraz gwarancji jego ochrony"15. Należ przy tym zaznaczać, że bezpieczeństwo obywateli nie jest tożsame z bezpieczeństwem państwa, a mieści się raczej w dużo szerszym pojęciu bezpieczeństwa narodowego.

W literaturze z zakresu nauki o bezpieczeństwie mocno wyeksponowane jest stanowisko, zgodnie z którym bezpieczeństwo narodowe rozszerza pojęcie bezpieczeństwo państwa o wartości i potrzeby bliskie jednostce i różnym grupom społecznym, a więc bardzo istotne w demokratycznym państwie prawnym ${ }^{16}$.

\footnotetext{
${ }^{14}$ Zob. więcej na temat preambuły w Konstytucji RP w K. STRZĘPEK, Znaczenie prawne wstępu do Konstytucji RP z 1997 roku, Warszawa: Wydawnictwo Sejmowe 2003.

${ }^{15}$ M. FlORCZAK-WąTor, Komentarz do art. 5, [w:] Konstytucja RP. Tom I. Komentarz do art. 1-86, red. M. Safian, L. Bosek, Warszawa: Wydawnictwo Beck 2016, s. 287-288.

${ }^{16}$ Oczywiście są też zwolennicy innego podejścia do zagadnienia bezpieczeństwa narodowego i bezpieczeństwa państwa m.in. S. Koziej choć wskazuje, że bezpieczeństwo narodowe i bezpieczeństwo państwa to różne kategorie pojęciowe, to uważa, że ze względów praktycznych można umownie traktować je jako tożsame. Zob. S. KozIEJ, Bezpieczeństwo: istota, podstawowe kategorie
} 
Zwolennikiem takiego podejścia jest W. Kitler, który wskazuje, że bezpieczeństwa narodowe to ,proces obejmujący różnorodne środki, gwarantujące trwały, wolny od zakłóceń byt i rozwój narodowy (państwa), w tym ochronę i obronę państwa jako instytucji politycznej oraz ochronę jednostek i całego społeczeństwa, ich dóbr i środowiska naturalnego przed zagrożeniami, które w znaczący sposób ograniczają jego funkcjonowania lub godzą w dobra podlegające szczególnej ochronie"17. Z kolei J. Czaja podkreśla, że bezpieczeństwo narodowe i bezpieczeństwo państwa to terminy stosowane wymiennie, ale nie tożsame. Na ogół ten pierwszy termin jest pojęciem obszerniejszym zawierającym w sobie zarówno bezpieczeństwo państwa, jak i narodu oraz jednostek naród ten tworzących" ${ }^{\text {"18 }}$. Natomiast B. Zdrodowski, wyraża bardzo zdecydowane stanowisko zgodnie z którym „różnice znaczeniowe narodu i państwa powodują, że utożsamianie bezpieczeństwa narodowego z bezpieczeństwem państwa nie powinno być uprawnione z punktu widzenia naukowego"19

W Konstytucji z 1997 r. pojęcie „bezpieczeństwo narodowe” nie występuje, jednak w art. 135 jako organ doradczy Prezydenta RP w zakresie bezpieczeństwa zewnętrznego i wewnętrznego państwa wymieniona jest Rada Bezpieczeństwa Narodowego. Natomiast samo pojęcie ,,bezpieczeństwo państwa” jest użyte w ustawie zasadniczej kilkukrotnie m.in. art. 53 ust. 5, art. 61 ust. 3, art. 126 ust. 2, art. $130^{20}$ Nie zmienia to faktu, że w świetle art. 5 Konstytucji, poglądy doktryny nauki o bezpieczeństwie wskazujące, że bezpieczeństwo narodowe rozszerza pojęcie bezpieczeństwo państwa o wartości i potrzeby bliskie jednostce i różnym grupom społecznym wydają się absolutnie zasadne.

Należy również zaznaczyć, że w Konstytucji oprócz „,bezpieczeństwa państwa” występują też pojęcia ,,bezpieczeństwo zewnętrzne”, „,bezpieczeństwo wewnętrzne”, „,bezpieczeństwo obywateli”, „,bezpieczeństwo granic”, „,bezpieczeństwo ekologicz-

i historyczna ewolucja, „Bezpieczeństwo Narodowe” 18 (2018), s. 20. Z kolei J. Pawłowski utożsamia bezpieczeństwo państwa z bezpieczeństwem narodowym: „Bezpieczeństwo narodowe to najwyższa wartość, potrzeba narodowa i priorytetowy cel działalności państwa, jednostek i grup społecznych, a jednocześnie proces obejmujący różnorodne środki, gwarantujące trwały, wolny od zakłóceń byt i rozwój narodowy (państwa) [...]". J. PAwıowski, System kierowania bezpieczeństwem narodowym - teoria i praktyka, [w:] Wspótczesny wymiar bezpieczeństwa. Między teoria a praktyka, red. J. Pawłowski, Warszawa: Wydawnictwo Stowarzyszenia Ruch Wspólnot Obronnych 2001, s. 56.

${ }^{17}$ W. KITLER, Bezpieczeństwo narodowe RP: podstawowe kategorie, uwarunkowania, system, Warszawa: Wydawnictwo Akademii Obrony Narodowej 2011, s. 31.

${ }^{18}$ L. Chojnowski, Bezpieczeństwo narodowe. Studium teoretyczne, Słupsk: Wydawnictwo Naukowe Akademii Pomorskiej 2016, s. 134.

${ }^{19}$ B. ZDRodowski, Rozważania o bezpieczeństwie państwa, [w:] Od sztuki wojennej do bezpieczeństwa narodowego, red. W. Kitler, Warszawa: Wydawnictwo Akademii Obrony Narodowej 2017, s. 607.

${ }^{20} \mathrm{Na}$ marginesie trzeba zaznaczyć, że w większości przepisów jest to „bezpieczeństwo państwa” (pisane małą literą), zaś w art. 130 „bezpieczeństwo Państwa” (pisane wielką literą). 
ne”. Wszystkie te rodzaje bezpieczeństwa mieszczą się w pojęciu „bezpieczeństwa narodowego", które jednak w ustawie zasadniczej nie występuje. W doktrynie nauki o bezpieczeństwie taka niespójność od lat poddawana jest krytyce wraz z postulatem ujednolicenia podstawowych pojęć.

Realizacja naczelnych celów państwa polskiego wskazanych w art. 5 ustawy zasadniczej, a więc m.in. strzeżenia niepodległości oraz nienaruszalności terytorium, a także zapewnianie bezpieczeństwa obywatelom, jest zadaniem organów władzy państwowej. Szczególna rola w tym zakresie spoczywa na Siłach Zbrojnych RP, które są jedyną formacją mundurową unormowaną w ustawie zasadniczej $\mathrm{i}$ to w dodatku wśród głównych zasad ustrojowych.

Zdaniem P. Sarneckiego Siłami Zbrojnymi RP są przede wszystkim obywatele, spełniający aktualnie swój obowiązek służby wojskowej (art. 85 Konstytucji $^{21}$ ) zarówno w sytuacji służby czynnej, służby zastępczej, służby rezerwowej, służby pomocniczej i ewentualnie dalszych jej rodzajów, tworzonych przepisami prawa, jak i obywatele wchodzący w skład Sił Zbrojnych poprzez realizację swojego prawa do wolności wyboru i wykonywania zawodu określonego w art. 65 ust. 1 ustawy zasadniczej ${ }^{22}$.

Natomiast W. Wołopiuk podkreśla, że odrębność organizacyjna i zadania Sił Zbrojnych wśród innych ogniw państwa nie oznaczają, że mają one status swoistych organów państwowych oraz że są samodzielnym podmiotem prawa publicznego ${ }^{23}$. Podobnie zdanie wyraża P. Grzebyk uwypuklając, że obecne rozwiązania konstytucyjne nie wskazują, że Siły Zbrojne RP są samoistnym organem państwa ${ }^{24}$, aczkolwiek istnieje obowiązek ich powołania wynikający z art. 26 oraz 134 ustawy zasadniczej ${ }^{25}$.

Na podstawie przepisów wspomnianego art. 134 Konstytucji Siły Zbrojnej RP muszą składać się z „rodzajów” wojsk, na czele których stoją „dowódcy” powoływani przez Prezydenta RP (ust. 134 ust. 3$)^{26}$. Głowa państwa jest zwierzchnikiem

\footnotetext{
${ }^{21}$ Więcej na temat regulującego obywatelski obowiązek obrony Ojczyzny art. 85 Konstytucji w dalszych częściach rozważań

22 P. SARNECKI, Komentarz do art. 26, [w:] Konstytucja Rzeczypospolitej Polskiej. Komentarz. Tom I, red. L. Garlicki, M. Zubik, Warszawa: Wydawnictwo Sejmowe 2016, s. 631.

${ }^{23}$ W. Wolpiuk, Sity Zbrojne w regulacjach Konstytucji RP, Warszawa: Wydawnictwo Scholar 1998, s. 17.

${ }^{24} \mathrm{~W}$ przeciwieństwie m.in. do konstytucji kwietniowej, gdzie art. 3 stanowił wprost że Siły Zbrojne są organami państwa pozostającymi pod zwierzchnictwem Prezydenta RP.

${ }^{25}$ P. GrzeByK, Komentarz do art. 26, [w:] Konstytucja RP. Tom I. Komentarz do art. 1-86, s. 687.

${ }^{26}$ Po reformie systemu dowodzenia w 2014 r. Siły Zbrojne RP zostały podzielne na Dowództwo Generalne Rodzajów Sił Zbrojnych oraz Dowództwo Operacyjne Rodzajów Sił Zbrojnych, zaś w 2016 r. utworzono jeszcze Dowództwo Wojsk Obrony Terytorialnej (jako trzeci rodzaj Sił Zbrojnych). Jednocześnie ograniczono kompetencje Szefa Sztabu Generalnego (powoływanego przez
} 
Sił Zbrojnych (art. 134 ust. 1) oraz sprawuje to zwierzchnictwo w okresie pokoju za pośrednictwem Ministra Obrony Narodowej (art. 134. ust. 2). Natomiast na czas wojny Prezydent na wniosek Rady Ministrów może powołać Naczelnego Dowódcę Sił Zbrojnych ${ }^{27}$.

Funkcje Sił Zbrojnych ustanowione w art. 26 ust. 1 oraz fakt, że są one wymienione w rozdziale dotyczącym zasad ustrojowych, dają podstawę do sformułowania konstytucyjnej zasady służebności Sił Zbrojnych w zakresie wykonywania zadań, do jakich są one przeznaczone w państwie. W opinii W. Wołpiuka art. 26 ust. 1 Konstytucji „wskazuje jako kierunek działalności Sił Zbrojnych ochronę ustalonych w normie konstytucyjnej wartości oraz określa granice służebnych zadań Sił Zbrojnych. Służenie ochronie oznacza również, że Siły Zbrojne wykonując powierzone im przez Konstytucję zadania nie są w pełni samodzielne, lecz służą ochronie ważnych wartości ustalonych przez suwerena i są podporządkowane organom władzy publicznej”28.

Ustawa o powszechnym obowiązku obrony w art. 3 ust. 1 rozszerza zakres zadań Sił Zbrojnych wskazując, że stoją one na straży suwerenności i niepodległości Narodu Polskiego oraz jego bezpieczeństwa i pokoju. Ponadto zgodnie z art. 3 ust. 2 tego aktu normatywnego „Siły Zbrojne mogą brać udział w zwalczaniu klęsk żywiołowych i likwidacji ich skutków, działaniach antyterrorystycznych i z zakresu ochrony mienia, akcjach poszukiwawczych oraz ratowania lub ochrony zdrowia i życia ludzkiego, oczyszczaniu terenów z materiałów wybuchowych i niebezpiecznych pochodzenia wojskowego oraz ich unieszkodliwianiu, a także w realizacji zadań z zakresu zarządzania kryzysowego"29. Tak więc realizując swoje konstytucyjne zadania Siły Zbrojne mogą być użyte w demokratycznym państwie zarówno do realizacji misji zapewniania bezpieczeństwa zewnętrznego, jak też do pomocy innym formacjom mundurowym i organom państwa w realizacji ochrony bezpieczeństwa wewnętrznego ${ }^{30}$.

Prezydenta na postawie art. 134 ust. 3 Konstytucji), który posiada głównie kompetencje doradcze (we wcześniejszych rozwiązaniach prawnych Minister Obrony Narodowej kierował rodzajami Sił Zbrojnych za pośrednictwem Szefa Sztabu Generalnego).

${ }^{27}$ Zob. więcej na temat Naczelnego Dowódcy Sił Zbrojnych w M. KoŁodzIEJCZAK, The Commander-in-Chief in Command and Control System of the Republic of Poland, „Journal on Baltic Security" 2 (2016), s. 80-101.

${ }^{28}$ Wolpiuk, Sity Zbrojne w regulacjach Konstytucji RP, s. 23.

${ }^{29}$ Ustawa z dnia 21 listopada 1967 r. o powszechnym obowiązku obrony Rzeczypospolitej Polskiej, Dz. U. z 2019 r., poz. 1541.

${ }^{30}$ Zob. więcej na temat wewnętrznej roli Sił Zbrojnych: M.A. KAMIŃSKI, Uwarunkowania prawno-organizacyjne wspótpracy Policji i Sit Zbrojnych RP $w$ działaniach kontrterrorystycznych w budynkach użyteczności publicznej, [w:] Bezpieczeństwo antyterrorystyczne budynków użyteczności 
Zasada służebności nie jest jedyną zasadą konstytucyjną dotyczącą Sił Zbrojnych, albowiem w art. 26 ust. 2 ustawy zasadniczej sformułowano jeszcze zasadę neutralności Sił Zbrojnych w sprawach politycznych oraz zasadę ich podległości cywilnej i demokratycznej kontroli. W orzeczeniu Trybunału Konstytucyjnego z 10 kwietnia 2002 r. podkreślono, że członkowie Sił Zbrojnych mogą podlegać daleko większym ograniczeniom w imię politycznej neutralności Sił Zbrojnych chroniących byt państwa, niż pozostałe grupy społeczeństwa. Jednocześnie Trybunał Konstytucyjny zaznaczył, że ,polityczna neutralność Sił Zbrojnych ma dwa aspekty - po pierwsze oznacza, że Siły Zbrojne nie mogą stanowić autonomicznego podmiotu w strukturze politycznej państwa, zdolnego do wywierania wpływu na polityczne decyzje konstytucyjnych organów państwa. Gwarancją tego aspektu neutralności politycznej Sił Zbrojnych jest cywilna kontrola nad Siłami Zbrojnymi, zapewniająca podległość wojska konstytucyjnym organom Rzeczypospolitej. Drugim aspektem politycznej neutralności Sił Zbrojnych jest wyłączenie tej struktury państwowej ze sfery bezpośredniego oddziaływania partii politycznych" ${ }^{\text {. }}$. Zasada neutralności politycznej skutkuje więc w konsekwencji ograniczeniem wolności zrzeszania się żołnierzy zawodowych. Ustawa o służbie wojskowej żołnierzy zawodowych wprowadza w tym zakresie szereg ograniczeń m.in. żołnierze nie mogą należeć do partii politycznych ani wspierać ich działalności, uczestniczyć w zgromadzeniach o charakterze politycznym, tworzyć związków zawodowych, pełnić funkcji posła na Sejm RP, senatora, posła do Parlamentu Europejskiego, wójta, burmistrza i prezydenta miasta i innych ${ }^{32}$.

Zasada apolityczności Sił Zbrojnych wiąże się z zasadą cywilnej i demokratycznej kontroli nad Siłami Zbrojnymi. Zasady te należą do standardów demokratycznego państwa prawnego ${ }^{33}$. Rozwinięcie zasady cywilnej i demokratycznej kontroli nad Siłami Zbrojnymi oznacza w praktyce ustanowienie konstytucyjnych ram prawnych (rozwiniętych w ustawodawstwie zwykłym), które zapewniają skuteczny nadzór na działalnością Sił Zbrojnych ze strony organów władzy wykonawczej, ustawodawczej oraz sądowniczej, zarówno w okresie pokoju, kryzysu, jak i wojny. W opinii P. Sarneckiego zakres tej „kontroli” należy traktować bardzo

publiczne. Metody i narzędzia zamachów vs działania antyterrorystyczne i kontretrrorystyczne, red. B. Wiśniewska-Paź, M. Szostak, J. Stelmach, Toruń: Wydawnictwo Adam Marszałek 2018, s. 137-155.

${ }^{31}$ Wyrok Trybunału Konstytucyjnego z dnia 10 kwietnia 2002 r., sygn. akt K 26/00, Dz. U. Nr 56, poz. 517.

${ }^{32}$ Zob. więcej: komentarz do art. 105-110 ustawy o służbie wojskowej żołnierzy zawodowych, S. СномоnciK, Ustawa o stużbie wojskowej żolnierzy zawodowych. Komentarz, Toruń: Wydawnictwo Adam Marszałek 2019, s. 253-261.

33 Orzeczenie Trybunału Konstytucyjnego z dnia 9 czerwca 1997 r., sygn. akt K 24/96, Z.U. 1997/2/20. 
szeroko. Jest to kontrola o charakterze ogólnym, ściśle związana z konstytucyjnymi funkcjami Sił Zbrojnych i mającą za swój przedmiot głównie kontrolę takich przejawów działalności Sił Zbrojnych, które bezpośrednio służą realizacji tych celów. Do tej kontroli należy też włączyć kompetencje projektowania i uchwalania budżetu państwa, uchwalanie ustaw, czy też tworzenie przez odpowiednie podmioty doktryny obronnej ${ }^{34}$.

\section{OBYWATELSKI OBOWIĄZEK OBRONY OJCZYZNY}

Ważnym konstytucyjnym aspektem w zakresie funkcjonowania Sił Zbrojnych RP jest również obywatelski obowiązek obrony Ojczyzny zawarty w art. 85 ustawy zasadniczej. Miał on szczególne znaczenie w okresie kiedy polska armia składała się w dużej mierze z żołnierzy poborowych odbywających obowiązkową służbę wojskową. Jednak po reformie Sił Zbrojnych RP przeprowadzonej w latach 2008-2010 i przejściu na model armii zawodowej zakres tego obowiązku w czasie pokoju został dość ograniczony ${ }^{35}$. Tym niemniej należy podkreślić, że pobór nie został zlikwidowany tylko zawieszony, a jego przywrócenie zależy od decyzji politycznej. Należy też podkreślić, że obywatelski obowiązek obrony Ojczyzny odgrywa niezwykle istotną rolę zwłaszcza w czasie wojny.

Oczywiście obywatelski obowiązek obrony Ojczyzny nie może być rozpatrywany tylko w kategoriach służby wojskowej. Jak podkreślono w orzeczeniu Trybunału Konstytucyjnego z 9 czerwca 1997 r.: „obowiązek obrony Ojczyzny został sformułowany ogólnie, bez wskazania co należy rozumieć pod pojęciem obrona Ojczyzny. Tylko szeroka interpretacja nadaje mu obecnie właściwy sens. Przez obronę Ojczyzny należy rozumieć całokształt działań mających na celu utrwalanie i ochronę różnych wartości takich jak niepodległość, pokój, kultura, gospodarka" ${ }^{36}$. Z kolei w innym orzeczeniu Trybunału Konstytucyjnego z 11 lutego 2003 r. wskazano, że „obowiązek obrony Ojczyzny ma charakter powszechny, choć może być wykonywany w rożnych formach. Podstawową jest odbycie służby wojskowej,

\footnotetext{
${ }^{34}$ SARNeCKI, Komentarz do art. 26, s. 636-637.

${ }^{35}$ M.A. KAmIŃsKi, Profesjonalizacja i modernizacja techniczna Sit Zbrojnych RP $w$ pracach ustawodawczych (2008-2010), [w:] Przestepczość w XXI wieku-zapobieganie i zwalczanie. Problemy prawno-kryminologiczne, red. E. Pływaczewski, W. Filipkowski, Z. Rau, Warszawa: Wolters Kluwer 2015, s. 308-323.

${ }^{36}$ Orzeczenie Trybunału Konstytucyjnego z dnia 9 czerwca 1997 r., sygn. akt K 24/96, Z.U. 1997/2/20.
} 
której zakres - według art. 85 ust. 2 Konstytucji - określa ustawa"37. Tym aktem normatywnym jest ustawa z 21 listopada 1967 r. o powszechnym obowiązku obrony Rzeczypospolitej Polskiej, która w art. 4 ust. 2 oprócz służby wojskowej wskazuje również inne elementy, do których zobowiązani są obywatele polscy w ramach powszechnego obowiązku obrony m.in.: wykonywania obowiązków wynikających z nadanych przydziałów kryzysowych i przydziałów mobilizacyjnych, świadczenia pracy $w$ ramach pracowniczych przydziałów mobilizacyjnych, pełnienia służby w obronie cywilnej, odbywania edukacji dla bezpieczeństwa, uczestniczenia w samoobronie ludności, odbywania ćwiczeń w jednostkach przewidzianych do militaryzacji i pełnienia służby w jednostkach zmilitaryzowanych, wykonywania świadczeń na rzecz obrony.

Należy podkreślić, że obowiązek obrony Ojczyzny wskazany w art. 85 ust. 1 Konstytucji dotyczy tylko i wyłącznie obywateli polskich ${ }^{38}$. Jednak w przypadku jeżeli obywatel polski posiada także obywatelstwo innego państwa (lub kilku państw) to nie zwalnia go to z obowiązku obrony Ojczyzny, gdyż zgodnie z art. 3 ust. 1 ustawy z 2 kwietnia 2009 r. o obywatelstwie polskim, ma on wobec Rzeczypospolitej Polskiej takie same prawa i obowiązki jak osoba posiadająca wyłącznie obywatelstwo polskie. Ponadto na podstawie art. 3 ust. 2 tego aktu normatywnego „obywatel polski nie może wobec władz Rzeczypospolitej Polskiej powoływać się ze skutkiem prawnym na posiadane równocześnie obywatelstwo innego państwa i na wynikające z niego prawa i obowiązki"39. Tym niemniej w ustawie o powszechnym obowiązku obrony w art. 4 przewidziano, że obywatel polski będący równocześnie obywatelem innego państwa nie podlega powszechnemu obowiązkowi obrony, jeżeli na stałe zamieszkuje poza granicami Rzeczypospolitej Polskiej ${ }^{40}$.

W doktrynie nauk prawnych wskazuje się, że użycie słowa „Ojczyzna” pisane wielką literą podkreśla moralny i patriotyczny charakter tego obowiązku. P. Grzebyk

${ }^{37}$ Wyrok Trybunału Konstytucyjnego z dnia 11 lutego 2003 r., sygn. akt P 12/02, Dz. U. Nr 35, poz. 312 .

${ }^{38}$ Podobny zakres ma jeszcze tylko zdefiniowany w art. 82 obowiązek wierności Rzeczypospolitej Polskiej i troski o dobro wspólne. Natomiast pozostałe obowiązki wymienione w Konstytucji - przestrzeganie prawa, ponoszenie ciężarów i świadczeń publicznych (w tym podatków), dbałość o stan środowiska - dotyczą już wszystkich (,każdy jest obowiązany do [...]”).

${ }^{39}$ Ustawa z dnia 2 kwietnia 2009 r. o obywatelstwie polskim, Dz. U. z 2018 r., poz. 1829.

${ }^{40}$ Po nowelizacji ustawy o powszechnym obowiązku obrony w 2005 r. obywatele polscy otrzymali formalną możliwość służby w siłach zbrojnych obcych państw lub obcej organizacji wojskowej. Jest to możliwe po uzyskaniu zgody ministra właściwego do spraw wewnętrznych, po zasięgnięciu opinii Ministra Obrony Narodowej i ministra właściwego do spraw zagranicznych. Natomiast w przypadku byłych żołnierzy zawodowych zgody udziela Minister Obrony Narodowej, po zasięgnięciu opinii ministra właściwego do spraw zagranicznych (zob. art. 199d). 
zwróciła uwagę, że posługiwanie się przez ustawodawcę pojęciem „Ojczyzna”, a nie „państwo polskie” czy „Rzeczypospolita Polska”, ma podkreślić wagę obowiązku i wyraźną wieź narodową i emocjonalną obywatela ze swoją Ojczyzną. Bardzo istotny jest też fakt, że „termin Ojczyzna skutkuje tym, iż obowiązek ten nie znika wraz z unicestwieniem struktur państwowych, czy w przypadku gdyby państwo polskie przestało być de facto podmiotem prawa międzynarodowego (np. w przypadku efektywnej okupacji i kompletnego zawojowania państwa polskiego, co jest obecnie prawnie niedopuszczalne, ale w praktyce możliwe)"41. Również K. Działocha zauważył, że Ojczyzna rozumiana jest jako kraj, w którym człowiek się urodził (lub w którym spędził znaczną część życia) i z którym czuje się związany emocjonalnie poczuciem przynależności do wspólnoty narodowej ukształtowanej poprzez historię, kulturę i język ${ }^{42}$.

\section{SŁUŻBA WOJSKOWA A WOLNOŚCI I PRAWA OBYWATELSKIE}

Trybunał Konstytucyjny w orzeczeniu z 16 lutego 1999 r. odniósł się do kwestii ograniczenia praw i wolności obywatelskich w kontekście obowiązku obrony Ojczyzny. W wyroku zwrócono uwagę, że służba wojskowa w każdym przypadku jest nieodłącznie związana $\mathrm{z}$ określonymi ograniczeniami swobody jednostki. Ograniczenia te dotykają niekiedy zasadniczych elementów kształtujących prawo do decydowania o swoim życiu osobistym. Zdaniem Trybunału Konstytucyjnego „nie może ulegać wątpliwości, że prawa jednostki zderzają się w tym przypadku z celowością ochrony interesu publicznego, związanego ściśle z ochroną bezpieczeństwa państwa, a więc tą wartością która w każdym demokratycznym porządku prawnym może, w granicach wyznaczonych niezbędnością uzasadnić wkroczenie w prawa jednostki, nawet prawa podstawowe" 43 .

W podobnym tonie utrzymane jest orzeczenie Trybunału Konstytucyjnego z 3 lipca 2001 r., w którym Trybunał Konstytucyjny stwierdził, że „uważa za fakt niewątpliwy, że pierwszą przyczyną, dla której prawa jednostki mogą być ograniczane jest ochrona dobra wspólnego, a w szczególności wzgląd na potrzeby bezpieczeństwa i obronności kraju" ${ }^{44}$. Jednocześnie w orzeczeniu Trybunału

\footnotetext{
${ }^{41}$ GrzebyK, Komentarz do art. 85, s. 1892.

42 K. Dziatocha, Komentarz do art. 85, [w:] Konstytucja Rzeczypospolitej Polskiej. Komentarz, s. 989.

${ }^{43}$ Wyrok Trybunału Konstytucyjnego z dnia 16 lutego 1999 r., sygn. akt SK 11/98, Dz. U. Nr 20, poz. 182 .

${ }^{44}$ Wyrok Trybunału Konstytucyjnego z dnia 3 lipca 2001 r., sygn. akt K 3/01, Dz. U. Nr 69 , poz. 725 .
} 
Konstytucyjnego z 25 listopada 2003 r. zwrócono uwagę, że ingerencja w prawa jednostki może mieć różną postać, zawsze jednak powinna być dokonywana w ramach obowiązującego prawa, w tym przede wszystkim z uwzględnieniem wartości konstytucyjnych. Wprowadzenie odpowiednich mechanizmów ustawowych w tym zakresie nie może prowadzić do naruszenia tych wartości i powinno respektować zasadę proporcjonalności ${ }^{45}$, wyrażoną w art. 31 ust. 3 Konstytucji który wskazuje, że „ograniczenia $\mathrm{w}$ zakresie korzystania z konstytucyjnych wolności i praw mogą być ustanawiane tylko w ustawie i tylko wtedy, gdy są konieczne w demokratycznym państwie dla jego bezpieczeństwa lub porządku publicznego, bądź dla ochrony środowiska, zdrowia i moralności publicznej, albo wolności i praw innych osób. Ograniczenia te nie mogą naruszać istoty wolności i praw".

Nawiązując do poszanowania godności człowieka oraz wolności sumienia i religii (art. 53 Konstytucji) ustawodawca zawarł w Konstytucji możliwość innej niż służba wojskowa formy wywiązywania się przez obywateli polskich z obowiązku obrony Ojczyzny. Zgodnie z art. 85 ust. 3 obywatel, któremu przekonania religijne lub wyznawane zasady moralne nie pozwalają na odbywanie służby wojskowej, może być obowiązany do służby zastępczej na zasadach określonych w ustawie. Szczegółowe rozwiązania prawne dotyczące tej materii znalazły się w ustawie z 28 listopada 2003 r. o służbie zastępczej. Na podstawie art. 2 tej ustawy służba zastępcza polega na wykonywaniu prac na rzecz ochrony środowiska, ochrony przeciwpożarowej, ochrony zdrowia, pomocy społecznej, opieki nad osobami niepełnosprawnymi albo bezdomnymi oraz na rzecz administracji publicznej i wymiaru sprawiedliwości i może odbyć się w państwowych i samorządowych jednostkach organizacyjnych, podmiotach leczniczych niebędących przedsiębiorcami, o których mowa w przepisach o działalności leczniczej, oraz w organizacjach pożytku publicznego ${ }^{46}$. W przypadku służby zastępczej istnieje bardzo bogate orzecznictwo sądów administracyjnych, jak też Trybunału Konstytucyjnego ${ }^{47}$.

\footnotetext{
${ }^{45}$ Wyrok Trybunału Konstytucyjnego z dnia 25 listopada 2003 r., sygn. akt K 37/02, M. P. Nr 56, poz. 877.

${ }^{46}$ Ustawa z dnia 28 listopada 2003 r. o służbie zastępczej, Dz. U. z 2018 r., poz. 885.

${ }^{47} \mathrm{~W}$ tym miejscu należy jednak ponownie podkreślić, że w związku z zawieszeniem obowiązkowej służby wojskowej w 2009 r. i przejściem na model armii zawodowej rozwiązania dotyczące służby zastępczej nie są obecnie stosowane. Tym niemniej w przypadku ewentualnego powrotu do systemu poboru kwestia służby zastępczej ponownie stanie się aktualna.
} 


\section{KOMPETENCJE NACZELNYCH ORGANÓW PAŃSTWA W ZAKRESIE OBRONNOŚCI I BEZPIECZEŃSTWA}

Funkcje Sił Zbrojnych RP powiązane są z konstytucyjnymi kompetencjami naczelnych organów państwa w zakresie obronności i bezpieczeństwa. Kluczowa rola przypada w tym aspekcie zwłaszcza organom władzy wykonawczej (Prezydent RP i Rada Ministrów) oraz ustawodawczej (Sejm RP).

Zgodnie z art. 126 ust. 2 ustawy zasadniczej Prezydenta RP m.in. stoi na straży suwerenności i bezpieczeństwa państwa oraz nienaruszalności i niepodzielności jego terytorium. Są to funkcje zbieżne z naczelnymi celami państwa (art. 5 Konstytucji) oraz zadaniami Sił Zbrojnych (art. 26 ust. 1). Prezydent RP jest najwyższym zwierzchnikiem Sił Zbrojnych (art. 134 ust. 1) i realizuje to zwierzchnictwo w czasie pokoju za pośrednictwem Ministra Obrony Narodowej (art. 134 ust. 2). Kompetencje Prezydenta w zakresie zwierzchnictwa nad Siłami Zbrojnymi określa ustawa (art. 134 ust. 6). Właściwym aktem normatywnym jest w tym zakresie ustawa o powszechnym obowiązku obrony ${ }^{48}$, natomiast kompetencje Ministra Obrony Narodowej uregulowane są również w ustawie z 14 grudnia 1995 r. o urzędzie Ministra Obrony Narodowej ${ }^{49}$.

Do konstytucyjnych kompetencji głowy państwa w dziedzinie obronności należy również m.in. mianowanie na czas wojny na wniosek Prezesa Rady Ministrów Naczelnego Dowódcy Sił Zbrojnych (art. 134 ust. 4 Konstytucji), mianowanie Szefa Sztabu Generalnego i dowódców rodzajów Sił Zbrojnych (art. 134 ust. 3), nadawanie na wniosek Ministra Obrony Narodowej stopni wojskowych (art. 134 ust. 5), zarządzanie na wniosek Prezesa Rady Ministrów powszechnej lub częściowej mobilizacji i użycie Sił Zbrojnych do obrony Rzeczypospolitej Polskiej w razie bezpośredniego, zewnętrznego zagrożenia państwa (art. 136). Ponadto Prezydent RP posiada konstytucyjne kompetencje do wprowadzenia na wniosek Rady Ministrów stanu wojennego (art. 229) oraz stanu wyjątkowego (art. 230) na części lub na całym terytorium państwa.

Natomiast Rada Ministrów na podstawie art. 146 Konstytucji prowadzi politykę wewnętrzną i zagraniczną Rzeczypospolitej Polskiej, a w szczególności: zapewnia bezpieczeństwo wewnętrze państwa oraz porządek publiczny (art. 146 ust. 7), bezpieczeństwo zewnętrzne państwa (art. 146 ust. 8), a także sprawuje ogólne kierownictwo w dziedzinie obronności państwa oraz określa corocznie liczbę obywateli powoływanych do czynnej służby wojskowej (art. 146 ust. 11). Ponadto

48 Dz. U. z 1967 r. Nr 44, poz. 220 z późn. zm.

${ }^{49}$ Ustawa z dnia 14 grudnia 1995 r. o urzędzie Ministra Obrony Narodowej, Dz. U. z 2019 r., poz. 196. 
Rada Ministrów m.in. zapewnia wykonywanie ustaw, wydaje rozporządzania oraz uchwala projekt budżetu państwa (dotyczący m.in. działu „obronność państwa”). Należy też podkreślić, że Prezes Rady Ministrów i Rada Ministrów może wystąpić do Prezydenta RP z szeregiem wniosków dotyczących obrony narodowej (m.in. w przypadku stanu wojennego, stanu wyjątkowego, mobilizacji, użycia Sił Zbrojnych do obrony państwa, mianowania Naczelnego Dowódcy Sił Zbornych i innych). Szczególną rolę w zakresie obrony państwa zajmuje Minister Obrony Narodowej, który kieruje całokształtem działalności Sił Zbrojnych. Minister Obrony Narodowej $\mathrm{z}$ jednej strony kieruje działem administracji rządowej obrona narodowa (a więc jako członek Rady Ministrów podlega bezpośrednio Prezesowi Rady Ministrów), a z drugiej strony jest organem, za pośrednictwem którego Prezydent RP sprawuje zwierzchnictwo nad Siłami Zbrojnymi w okresie pokoju.

Również Sejm $\mathrm{RP}^{50}$ jako organ władzy ustawodawczej posiada konstytucyjne kompetencje w zakresie obrony państwa m.in. decyduje w imieniu Rzeczypospolitej Polskiej o stanie wojny i o zawarciu pokoju (art. 116 ust. 1 Konstytucji). Sejm może podjąć uchwałę o stanie wojny jedynie w razie zbrojnej napaści na terytorium Rzeczypospolitej Polskiej lub gdy z umów międzynarodowych wynika zobowiązanie do wspólnej obrony przeciwko agresji (art. 116 ust. 2). Ponadto Sejm uchwala ustawy (w tym dotyczące obrony narodowej i powszechnego obowiązku obrony), podejmuje decyzję w drodze ustawy o upoważnieniu Prezydenta RP do ratyfikacji umów międzynarodowych (m.in. dotyczących sojuszy, układów politycznych lub układów wojskowych), rozpatruje rozporządzenie Prezydenta w sprawie wprowadzenia stanu wojennego i stanu wyjątkowego (art. 231) oraz sprawuje funkcję kontrolną nad działalnością Rady Ministrów (art. 95 ust. 2). Ważną rolę w zakresie funkcji kontrolnej odgrywają zwłaszcza sejmowa Komisja Obrony Narodowej oraz Komisja ds. Służb Specjalnych ${ }^{51}$.

W nawiązaniu do kompetencji poszczególnych organów państwa w zakresie wprowadzenia stanu wojennego, stanu wyjątkowego i stanu klęski żywiołowej trzeba podkreślić, że w każdym z trzech stanów nadzwyczajnych istotne zadania wypełniają Siły Zbrojne RP. Jednak ich zakres jest zróżnicowany, co szczegółowo unormowano już w ustawodawstwie zwykłym. W przypadku stanu wojennego Siły

\footnotetext{
${ }^{50}$ Należy też zaznaczyć, że pewną rolę w zakresie obronności odgrywa również druga izba parlamentu - Senat RP, m.in. kwestie związane z udziałem w procesie ustawodawczym, uchwalaniem budżetu czy też pracą Senackiej Komisji Obrony Narodowej. Jednak nie odgrywają one tak zasadniczej roli jak opisane kompetencje Sejmu RP.

${ }^{51}$ M.A. KAmIŃski, Status prawny i praktyka funkcjonowania podkomisji w Sejmie RP, „Przegląd Sejmowy" 4 (2018), s. 26.
} 
Zbrojne pełnią absolutnie wiodącą funkcje $\mathrm{e}^{52}$, natomiast w sytuacji stanu wyjątkowego i stanu klęski żywiołowej jest to raczej funkcja pomocnicza. Użycie Sił Zbrojnych może bowiem nastąpić w sytuacjach szczególnych, kiedy inne służby mundurowe i organy cywilne nie radzą sobie z opanowaniem sytuacji. Zgodnie z art. 11 ust. 1 ustawy z 21 czerwca 2002 r. o stanie wyjątkowym można podjąć decyzje o użyciu oddziałów i pododdziałów Sił Zbrojnych RP do przywrócenia normalnego funkcjonowania państwa, jeżeli dotychczas zastosowane siły i środki zostały wyczerpane ${ }^{53}$. Podobnie na podstawie art. 18 ust. 1 ustawy z 18 kwietnia 2002 r. o stanie klęski żywiołowej jeżeli użycie innych sił i środków jest niemożliwe lub niewystarczające, można przekazać do dyspozycji wojewody pododdziały lub oddziały Sił Zbrojnych RP, wraz ze skierowaniem ich do wykonywania zadań związanych z zapobieżeniem skutkom klęski żywiołowej lub ich usunięciem ${ }^{54}$.

\section{BADANIA PORÓWNAWCZE}

Przystępując do analizy porównawczej unormowań konstytucyjnych 8 państw członkowski Sojuszu Północnoatlantyckiego w zakresie sił zbrojnych należy poczynić uwagę, że posiadają one różne modele służby wojskowej. Część państw podobnie jak Polska przeprowadziła proces profesjonalizacji sił zbrojnych, zawiesiła pobór i przeszła na system armii zawodowej - Francja (od 2001 r.), Hiszpania (od 2001 r.), Czechy (od 2005 r.), Niemcy (od 2011 r.). Natomiast pozostałe państwa posiadają model armii poborowej, przy czym realizowany w różnym zakresie. Estonia i Grecja wdrażają system obowiązkowej służby wojskowej oparty na powszechnym obowiązku obrony Ojczyzny (który obejmuje wszystkich mężczyzn w określonym wieku i odpowiednim stanie zdrowia). Natomiast w Danii i Norwegii występuje „miękka wersja” poboru - choć formalnie funkcjonuje system obowiązkowej służby wojskowej to do armii wciela się głównie ochotników. Trzeba też zaznaczyć, że Norwegia jest pierwszym państwem NATO, które wprowadziło obowiązkową służbę wojskową bez rozróżnienia na płeć (od 2015 r.).

Konstytucja Republiki Federalnej Niemiec z 23 maja 1949 r. ${ }^{55}$ zawiera bardzo szeroki katalog przepisów dotyczących sił zbrojnych i obronności państwa. Klu-

\footnotetext{
${ }^{52}$ Ustawa z dnia 14 grudnia 1995 r. o stanie wojennym oraz o kompetencjach Naczelnego Dowódcy Sił Zbrojnych i zasadach jego podległości konstytucyjnym organom Rzeczypospolitej Polskiej, Dz. U. z 2017 r., poz. 1932.

${ }^{53}$ Ustawa z dnia 21 czerwca 2002 r. o stanie wyjątkowym, Dz. U. z 2017 r., poz. 1928.

${ }^{54}$ Ustawa z dnia 18 kwietnia 2002 r. o stanie klęski żywiołowej, Dz. U. z 2017 r., poz. 1897.

${ }^{55}$ Ustawa Zasadnicza Republiki Federalnej Niemiec z 23 maja 1949 r., thum. B. Banaszak, A. Malicka, [w:] http://libr.sejm.gov.pl/tek01/txt/konst/niemcy.html [dostęp: 30.03.2019].
} 
czowe rozwiązania prawne w zakresie zadań i organizacji sił zbrojnych znajdują się w rozdziale VIII określającym zagadnienia wykonywania ustaw federalnych i administracji federalnej. Artykuł 87a normuje m.in., że „Federacja utrzymuje siły zbrojne w celu obrony, a ich liczebność oraz zasady organizacji muszą wynikać z budżetu”, zaś siły zbrojne poza obroną państwa mogą być użyte jedynie wtedy, gdy Konstytucja wyraźnie na to zezwala. W omawianym przepisie uregulowane są również przypadki szczególnego użycia sił zbrojnych m.in. w stanie obrony i w stanie napięcia do ochrony obiektów cywilnych i realizacji zadań z zakresu regulacji ruchu, zaś w sytuacji koniecznej dla odparcia niebezpieczeństwa grożącego istnieniu demokratycznego ustroju Federacji lub jednego z krajów związkowych, do ochrony obiektów cywilnych oraz zwalczania zorganizowanych i uzbrojonych militarnie powstańców. Ponadto art. $87 \mathrm{~b}$ stanowi, że administracja wojskowa jest sprawowana $\mathrm{w}$ ramach własnej administracji federalnej poprzez własny system organów administracyjnych. Dodatkowo w art. 26 ust. 1 przewidziano, że działania które mogą zakłócić pokojowe współżycie narodów i są podejmowane z takim zamiarem, w szczególności przygotowania do prowadzenia wojny zaczepnej, są sprzeczne z konstytucją i podlegają one karze.

Natomiast bardzo rozbudowany art. 12a (znajdujący się w rozdziale I ustawy zasadniczej „Prawa podstawowe”) normuje kwestie obowiązkowej służby wojskowej i świadczeń na rzecz obrony państwa. Choć w Niemczech od 1 lipca 2011 r. zawieszono pobór do Bundeswehry i wdrożono system armii zawodowej ${ }^{56}$, to przepis art. 12a nadal obowiązuje, a na jego podstawie „mężczyźni po ukończeniu osiemnastego roku życia mogą być zobowiązani do służby w siłach zbrojnych, w Federalnej Straży Granicznej lub w jednostce obrony cywilnej”. Jednocześnie uwzględniono, że w sytuacji, gdy ze względów sumienia odmawia się służby wojskowej z bronią w ręku, można zostać zobowiązanym do służby zastępczej. Ponadto w art. 12a ust. 4 uregulowano, że, jeżeli w stanie obrony zapotrzebowanie na cywilne świadczenia publiczne w cywilnej służbie sanitarnej i zdrowia oraz w stacjonarnych szpitalach wojskowych nie może być pokryte na zasadzie dobrowolności, kobiety od osiemnastego do pięćdziesiątego piątego roku życia mogą zostać przez ustawę lub na podstawie ustawy powołane do tego rodzaju świadczeń publicznych. W żadnym wypadku nie mogą one zostać zobowiązane do pełnienia służby z bronią w ręku". W stosunku do osób które pełnią służbę w siłach zbrojnych lub pozostających w służbie zastępczej, ustawa zasadnicza $\mathrm{w}$ art. 17 a przewiduje możliwość ograniczania ich podstawowych praw do swobodnego wyrażania i rozpowszechniania poglądów (w słowie, piśmie i obrazie), prawa wolności zgromadzeń oraz prawa petycji.

${ }^{56}$ W Niemczech ciągle trwa dyskusja nad przywróceniem poboru (przynajmniej w ograniczonym zakresie) zob. http://www.defence24.pl/niemcy-przywroca-pobor-watpliwosci [dostęp: 30.03.2019]. 
W niemieckiej konstytucji znajduje się też szereg unormowań dotyczących kompetencji organów państwa w stosunku do sił zbrojnych (choć zasada cywilnej kontroli nad armią nie jest wyrażona wprost tak jak w Konstytucji RP), m.in. Federalny Minister Obrony ma prawo wydawania rozkazów i sprawuje dowództwo nad siłami zbrojnymi (art. 65a), prawo wydawania rozkazów i sprawowanie dowództwa nad siłami zbrojnymi przechodzi na Kanclerza Federalnego z chwilą ogłoszenia stanu obrony (art. 115b), powołuje się Pełnomocnika Bundestagu do Spraw Sił Zbrojnych dla ochrony praw podstawowych i jako organ pomocniczy Bundestagu w sprawowaniu kontroli parlamentarnej (art. 45b), Bundestag powołuje Komisję Spraw Zagranicznych i Komisję Obrony (art. 45a).

W niemieckiej ustawie zasadniczej znajduje się również odrębny rozdział (składający się z 11 rozbudowanych artykułów) regulujący kwestię stanu obrony, który jako stan nadzwyczajny, zgodnie z art. 115a może być wprowadzony w przypadku stwierdzenia, że obszar Federacji został zbrojnie zaatakowany, lub że istnieje bezpośrednia groźba takiego ataku.

W kolejnym analizowanym państwie - Francji - rozwiązania konstytucyjne dotyczące sił zbrojnych i obronności państwa nie są tak rozbudowane jak w przypadku niemieckiej ustawy zasadniczej. Tym niemniej należy zaznaczyć, że w art. XII Deklaracji Praw Człowieka i Obywatela z 26 sierpnia 1789 r. ${ }^{57}$ (która jest częścią francuskiego porządku konstytucyjnego) stwierdzono, że „zagwarantowanie praw Człowieka i Obywatela wymaga istnienia publicznej siły zbrojnej: siła ta jest więc ustanowiona $\mathrm{w}$ interesie wszystkich, a nie tylko dla wygody tych, którym została powierzona", zaś w art. XIII dodano, że w celu utrzymania publicznej siły zbrojnej oraz dla pokrycia wydatków administracji niezbędny jest podatek powszechny, który powinien być równo rozłożony na wszystkich Obywateli stosownie do ich możliwości.

Natomiast w samej Konstytucji Republiki Francuskiej z 4 października 1958 r. $^{58}$ znajdują się głównie regulacje dotyczące kompetencji organów państwa w zakresie sił zbrojnych. Na podstawie art. 15 Prezydent Republiki jest zwierzchnikiem sił zbrojnych oraz przewodniczy najwyższym radom i komitetom obrony narodowej. Natomiast zgodnie z art. 20 Rząd określa i prowadzi politykę Narodu, a także dysponuje administracją i siłami zbrojnymi. Dodatkowo art. 21 stanowi, że Premier kieruje działalnością Rządu i ponosi odpowiedzialność za obronę narodową oraz obsadza stanowiska cywilne i wojskowe. Do decyzji Parlamentu na podstawie art.

${ }^{57}$ Deklaracja praw człowieka i obywatela z 26 sierpnia 1789 r., tłum. W. Skrzydło, [w:] http:// biblioteka.sejm.gov.pl/wp-content/uploads/2015/10/Francja_pol_010711.pdf [dostęp: 30.03.2019].

${ }^{58}$ Konstytucja Republiki Francuskiej z 4 października 1958 r., tłum. W. Skrzydło, [w:] http:// biblioteka.sejm.gov.pl/wp-content/uploads/2015/10/Francja_pol_010711.pdf [dostęp: 30.03.2019]. 
35 należy zaś wypowiedzenie wojny oraz decyzja co do interwencji sił zbrojnych poza granicami Francji (jeżeli interwencja przekracza okres czterech miesięcy, gdyż w innym przypadku decyduje Rząd).

Z kolei w Hiszpanii zagadnienia dotyczące obronności państwa i sił zbrojnych mają dość szeroki zakres i znajdują się w różnych miejscach ustawy zasadniczej z 27 grudnia 1978 r. ${ }^{59}$ Na podkreślenie zasługuje fakt, że przepisy określające status i zadania sił zbrojnych umieszczono we wstępnym rozdziale ustawy zasadniczej. W art. 8 Konstytucji Królestwa Hiszpanii unormowano, że „siły zbrojne, złożone z wojsk lądowych, marynarki i wojsk lotniczych, mają za zadanie zapewnienie suwerenności i niezawisłości Hiszpanii, obronę jej integralności terytorialnej i porządku konstytucyjnego". Dodatkowo stwierdzono, że ustawa organiczna określi podstawy organizacji sił zbrojnych, zgodnie z zasadami Konstytucji.

W rozdziale II „O podstawowych prawach i obowiązkach” w art. 30 uregulowano kwestię obowiązku obrony Ojczyzny stanowiąc, że Hiszpanie mają prawo i obowiązek obrony Hiszpanii, a ustawa określi „obowiązki wojskowe Hiszpanów i ureguluje, z zachowaniem odpowiednich gwarancji, sprzeciw ze względów sumienia, jak również inne przyczyny zwolnienia od obowiązkowej służby wojskowej, mogąc, w takich wypadkach, nałożyć obowiązek społecznych świadczeń zastępczych". W omawianym artykule unormowano też, że w drodze ustawy mogą być określone obowiązki obywateli w wypadku poważnego niebezpieczeństwa, katastrofy lub klęski powszechnej. W art. 29 wprowadzono możliwość ograniczenia lub wyłączenia prawa do swobodnego zrzeszania się w związki zawodowe w siłach lub formacjach zbrojnych albo w stosunku do pozostałych instytucji poddanych dyscyplinie wojskowej.

W zakresie uprawnień poszczególnych organów państwa w zakresie sił zbrojnych zgodnie z art. 149 ust. 4 Konstytucji Hiszpanii sprawy obrony i sił zbrojnych należą do wyłącznej kompetencji państwa. Król jest naczelnym dowódcą sił zbrojnych oraz obsadza stanowiska cywilne i wojskowe (art. 62), a Rząd kieruje polityką wewnętrzną i zewnętrzną, administracją cywilną i wojskową oraz obroną państwa (art. 97). Hiszpańska ustawa zasadnicza w art. 116 reguluje również trzy stany nadzwyczajne: stan pogotowia, stan wyjątkowy i stan oblężenia.

Natomiast w Konstytucji Grecji z 9 czerwca 1975 r. ${ }^{60}$ obywatelski obowiązek obrony Ojczyzny uregulowano w art. 4 ust. 6, na podstawie którego każdy Grek, zdolny do noszenia broni, jest obowiązany uczestniczyć w obronie Ojczyzny

${ }^{59}$ Konstytucja Hiszpanii z 27 grudnia 1978 r., thum. T. Mołdawa, [w:] http://biblioteka.sejm.gov. pl/wp-content/uploads/2015/10/Hiszpania_pol_300612.pdf [dostęp: 30.03.2019].

${ }^{60}$ Konstytucja Grecji z 9 czerwca 1975 r., thum. G. Ulicka, W. Ulicki, B. Zdaniuk i in.], [w:] http://biblioteka.sejm.gov.pl/wp-content/uploads/2015/10/Grecja_pol_010711.pdf [dostęp: 30.03.2019]. 
zgodnie z postanowieniami ustawy. Jednocześnie jednak w ustawie zasadniczej wprowadzono „deklaracje wyjaśniającą” do tego przepisu, która stanowi, że postanowienia te „nie wykluczają, aby ustawa przewidziała obowiązkowe odbywanie służby zastępczej, w obrębie sił zbrojnych lub poza nimi, przez tych, którzy z uzasadnionych względów sumienia wyrażają sprzeciw wobec odbywaniu służby wojskowej z użyciem broni lub wobec służby wojskowej w ogóle".

W greckiej ustawie zasadniczej nie ma przepisu dotyczącego funkcji i zadań sił zbrojnych. Znajdują się natomiast rozwiązania prawne dotyczące neutralności politycznej żołnierzy - art. 29 wprowadza bezwzględny zakaz okazywania w jakiejkolwiek formie „sympatii lub niechęci do jakiejkolwiek partii politycznej” m.in. wojskowym oraz funkcjonariuszom organów bezpieczeństwa. Natomiast art. 56 normuje, że wyżsi oficerowie sił zbrojnych i sił bezpieczeństwa „nie mogą kandydować ani zostać wybrani na deputowanych w żadnym okręgu wyborczym, w którym pełnili swoje funkcje lub w okręgu wyborczym, na który rozciągała się ich kompetencja terytorialna w ciągu ostatnich 18 miesięcy czteroletniej kadencji Izby Deputowanych". Artykuł 18 ustanawia możliwość rekwizycji na potrzeby sił zbrojnych w razie wojny lub mobilizacji, lub w warunkach najwyższej konieczności spowodowanej bezpośrednim zagrożeniem porządku lub zdrowia publicznego, zaś na podstawie art. 27 żadne obce wojska nie mogą zostać wpuszczone na terytorium Grecji, stacjonować na nim ani przemieszczać się w jego granicach, bez odpowiedniej ustawy (uchwalonej bezwzględną większością głosów ogólnej liczby deputowanych).

W Konstytucji Grecji znajdują się również inne przepisy dotyczące kompetencji naczelnych organów państwa w stosunku do sił zbrojnych i obronności państwa. Zgodnie z art. 36 Prezydent Republiki reprezentuje państwo w stosunkach międzynarodowych, wypowiada wojnę, zawiera traktaty pokojowe, sojusze, umowy dotyczące m.in. udziału w organizacjach lub związkach międzynarodowych ${ }^{61}$. Ponadto na podstawie art. 45 Prezydent Republiki jest zwierzchnikiem sił zbrojnych, a dowództwo nad nimi sprawuje Rząd, na zasadach określonych w ustawie. Prezydent nadaje także stopnie wojskowe osobom służącym w siłach zbrojnych. W greckiej ustawie zasadniczej uregulowano również kwestie stanu wyjątkowego, który zgodnie z art. 48 można wprowadzić „,w razie wojny, mobilizacji zarządzonej ze względu na niebezpieczeństwo zewnętrzne lub bezpośrednie zagrożenie bezpieczeństwa narodowego, jak również w przypadku ujawnienia działań zbrojnych, mających na celu obalenie ustroju demokratycznego".

${ }^{61}$ Prezydent ma obowiązek poinformowania o tym Izby Deputowanych, której udziela wszelkich niezbędnych wyjaśnień w takim zakresie, w jakim pozwalają na to interesy i bezpieczeństwo państwa. 
Z kolei Konstytucja Królestwa Danii z 5 czerwca 1953 r. ${ }^{62}$ zawiera bardzo niewiele unormowań dotyczących sił zbrojnych. Przede wszystkim w art. 81 uregulowano obywatelski obowiązek obrony Ojczyzny, którego konstrukcja bardzo przypomina rozwiązani greckie - „każdy mężczyzna zdolny do noszenia broni obowiązany jest do osobistego udziału w obronie swego kraju". Ponadto zgodnie z art. 19 ust. 2 z wyjątkiem obrony przed zbrojnym atakiem na Królestwo bądź na duńskie siły zbrojne, Król bez zgody Parlamentu (Folketingu) nie może użyć siły wojskowej przeciwko żadnemu z państw obcych. Każdy środek użyty przez Króla w wykonaniu tego postanowienia winien być bezzwłocznie przedłożony Folketingowi, a jeśli ten nie obraduje, to powinien być natychmiast zwołany. Dodatkowo w art. 55 przewidziano możliwość powołania przez Folketing jednej lub dwóch osób nie będących deputowanymi celem nadzorowania państwowej administracji cywilnej i wojskowej. Do sił zbrojnych odnosi się także art. 80 Konstytucji, zgodnie z którym „w przypadku rozruchów siły zbrojne winny nie podejmować akcji, dopóki nie zostaną zaatakowane, chyba że tłum, trzykrotnie wezwany w imieniu Króla i prawa do rozejścia się, zlekceważy to wezwanie".

Duńska ustawa zasadnicza reguluje także w art. 85 kwestię niektórych praw obywatelskich m.in. prawa do tworzenia stowarzyszeń (w tym o charakterze politycznym) i prawa do udziału w zgromadzeń (o niezbrojnym charakterze) stwierdzając, że w stosunku do sił zbrojnych znajdują zastosowanie tylko przy uwzględnieniu ograniczeń wynikających z przepisów ustaw wojskowych.

W kolejnym analizowanym państwie - Królestwie Norwegii - Konstytucja z 17 maja $1814 \mathrm{r}^{63} \mathrm{~W}$ niewielkim zakresie reguluje zagadnienia dotyczące sił zbrojnych i obronności państwa. Istotne znaczenie ma art. 109, który stanowi, że „każdy obywatel państwa z zasady jest jednakowo zobowiązany służyć przez określony czas w obronie Ojczyzny, bez względu na urodzenie lub majątek. Ustawa określa stosowanie tej zasady i jej ograniczenia".

Ponadto w norweskiej ustawie zasadniczej znajdują się zagadnienia dotyczące pozycji Króla, Rządu i Parlamentu (Stortingu) w zakresie obrony narodowej. Na podstawie art. 25 Król jest naczelnym dowódcą sił zbrojnych. Ponadto bez zgody Parlamentu (Stortingu) siły zbrojne nie mogą być zwiększone lub zredukowane oraz przekazane na służbę obcych państw. Dodatkowo bez zgody Stortingu siły zbrojne żadnego obcego państwa nie mogą być wprowadzone do Królestwa Norwegii (z wyjątkiem oddziałów pomocniczych dla obrony przed atakiem wroga).

${ }^{62}$ Konstytucja Królestwa Danii z 5 czerwca 1953 r., thum M. Grzybowski, [w:] http://biblioteka. sejm.gov.pl/wp-content/uploads/2015/07/Dania_pol_010811.pdf [dostęp: 30.03.2019].

${ }^{63}$ Konstytucja Królestwa Norwegii uchwalona przez Zgromadzenie Konstytucyjne w Eidsvold 17 maja 1814 r., thum. J. Osiński, [w:] http://biblioteka.sejm.gov.pl/wp-content/uploads/2016/02/ Norwegia_pol_010196.pdf [dostęp: 30.03.2019]. 
Omawiany przepis wskazuje także, że ,jednostki ochotników rezerwy i inne oddziały, które nie mogą być zaliczane do wojsk liniowych, nie mogą być nigdy użyte poza granicami Królestwa bez zgody Stortingu".

Na podstawie dalszych przepisów Konstytucji Norwegii Król ma prawo zarządzić mobilizację, rozpocząć wojnę w obronie kraju i zawrzeć pokój (art. 26). Wszystkie decyzje podjęte przez Króla wymagają dla swej ważności kontrasygnaty, zaś decyzje dotyczące dowództwa wojskowego są kontrasygnowane przez tego, kto przedstawiał sprawę, zaś inne przez Premiera lub w przypadku jego nieobecności przez najstarszego rangą obecnego członka Rady Państwa (art. 31). Dodatkowo Król wybiera i mianuje (po wysłuchaniu opinii Rady Państwa) wyższych urzędników wojskowych (art. 21) oraz może zwolnić (bez konieczności uprzedniego uzyskania orzeczenia sądu, ale po wysłuchaniu opinii Rady Państwa) dowódców pułków i innych formacji wojskowych, komendantów twierdz i oficerów dowodzących okrętami wojennymi (art. 22). Natomiast art. 99 norweskiej ustawy zasadniczej normuje, że „Rząd nie jest uprawniony do użycia sił zbrojnych przeciwko obywatelom państwa, inaczej niż w formie określonej w ustawodawstwie, chyba że jakieś zgromadzenie zakłóca spokój publiczny i nie rozprasza się niezwłocznie po trzykrotnym wyraźnym odczytaniu przez cywilnego urzędnika artykułów kodeksu dotyczących rozruchów".

Porządek konstytucyjny Republiki Czeskiej tworzą Konstytucja, Karta Podstawowych Praw i Wolności oraz ustawy konstytucyjne (ústavní zákony) uchwalane przez obie izby parlamentu większością trzech piątych głosów. Konstytucja Republiki Czeskiej z 16 grudnia 1992 r. ${ }^{64}$ traktuje zagadnienia dotyczące obronności państwa oraz funkcji sił zbrojnych w sposób bardzo oszczędny. W jej przepisach przede wszystkim wskazano na uprawnienia organów władzy ustawodawczej i wykonawczej w tym zakresie. Na podstawie art. 43 czeskiej ustawy zasadniczej Parlament m.in. podejmuje decyzję o wprowadzeniu stanu wojennego w razie napaści na Republikę Czeską lub konieczności wypełniania zobowiązań o wspólnej obronie przeciw napaści (ust. 1), podejmuje decyzję o udziale Republiki Czeskiej w systemach obronnych organizacji międzynarodowej (ust. 2), wyraża zgodę na wysłanie sił zbrojnych poza terytorium Republiki Czeskiej (ust. 3a) oraz na pobyt sił zbrojnych innych państw na terytorium Republiki Czeskiej, jeśli takie rozstrzygnięcia nie są zastrzeżone dla Rządu (ust. 3b). Na podstawie tego samego art. 43 ustawy zasadniczej Rząd podejmuje decyzje o wysłaniu sił zbrojnych poza terytorium Republiki Czeskiej oraz o pobycie sił zbrojnych innych państw na terytorium Republiki Czeskiej na okres nie dłuższy niż 60 dni w sytuacji, gdy chodzi

${ }^{64}$ Konstytucja Republiki Czeskiej z 16 grudnia 1992 r., tłum. M. Kruk-Jarosz, [w:] http://biblioteka.sejm.gov.pl/wp-content/uploads/2015/07/Czechy_pol_010811.pdf [dostęp: 30.03.2019]. 
o wypełnienie zobowiązań wynikających z umów międzynarodowych o wspólnej obronie przeciw napaści, udział w operacjach pokojowych na podstawie decyzji organizacji międzynarodowej oraz udział w działaniach ratunkowych w przypadku katastrof żywiołowych, awarii technicznych lub ekologicznych (ust. 4). Ponadto Rząd decyduje o przejeździe (lub przelocie) sił zbrojnych innych państw przez terytorium Republiki Czeskiej (ust. 5a), o udziale sił zbrojnych w ćwiczeniach wojskowych poza terytorium Republiki Czeskiej oraz o udziale sił zbrojnych innych państw w ćwiczeniach wojskowych na terytorium Republiki Czeskiej (ust. 5b). W zakresie kompetencji Prezydenta art. 63 ust. 1c Konstytucji wskazuje, że Prezydent jest naczelnym dowódcą sił zbrojnych.

Przepisy dotyczące służby wojskowej znajdują się również w Karcie Podstawowych Praw i Wolności z 16 grudnia 1992 r. (będącej częścią porządku konstytucyjnego Republiki Czeskiej). W art. 15 ust. 3 tego aktu normatywnego wskazano, że nikt nie może być zmuszony do wykonywania służby wojskowej, jeśli jest to niezgodne $\mathrm{z}$ jego sumieniem lub z jego wyznaniem religijnym. Dodatkowo w art. 9 ust. 1 zaznaczono, że nikt nie może być poddany przymusowym pracom lub służbom, jednak w ust. 2 wśród wyjątków od tej zasady wskazano, że postanowienia te nie odnoszą się do służby wojskowej lub innej służby ustanowionej ustawą w zastępstwie obowiązkowej służby wojskowej. Z kolei na podstawie art. 44 ograniczono członkom sił zbrojnych i sił bezpieczeństwa m.in. prawo do strajku, tworzenia związków zawodowych, prowadzenia działalności gospodarczej, składania petycji oraz uczestniczenia w pokojowych zgromadzeniach.

Natomiast ustawa konstytucyjna z 2 kwietnia 1998 r. w sprawie bezpieczeństwa Republiki Czeskiej ${ }^{65}$ jest aktem normatywnym najwyższej rangi poświęconym bezpośrednio kwestiom bezpieczeństwa i obronności państwa. W art. 1 ustawy unormowano, że podstawowymi zobowiązaniami państwa jest ochrona suwerenności i integralności terytorialnej Republiki Czeskiej oraz jej demokratycznych zasad, a także ochrona życia, zdrowia i własności. W art. 2 dodano, że jeżeli te wartości są zagrożone, podobnie jak wewnętrzny porządek i bezpieczeństwo, lub gdy muszą być spełnione międzynarodowe zobowiązania w dziedzinie wspólnej obrony, to można ogłosić stan wyjątkowy, stan zagrożenia dla bezpieczeństwa narodowego lub stan wojenny, w zależności od intensywności, zasięgu terytorialnego i charakteru sytuacji.

Ponadto w art. 3 ust. 1 ustawy konstytucyjnej wskazano, że bezpieczeństwo Republiki Czeskiej zapewniają jej siły zbrojne, uzbrojone formacje korpusu bezpie-

${ }^{65}$ Constitutional Act of Law No. 110/1998 Coll., of April, 22nd 1998, on Security of the Czech Republic, as amendmended by No. 300/2000 Coll., [w:] http://www.psp.cz/en/docs/laws/1998/110. html [dostęp: 30.08.2019]. 
czeństwa $^{66}$, korpus ratunkowy i służby ratownicze. Natomiast w ust. 2 ustanowiono ogólne zobowiązanie dla władz państwowych, jednostek samorządu terytorialnego oraz wszystkich osób fizycznych i prawnych do udziału w zapewnieniu bezpieczeństwa narodowego, zaznaczając, że zakres tego obowiązku i inne szczegółowe regulacje określają przepisy prawa.

W ustawie konstytucyjnej w sprawie bezpieczeństwa Republiki Czeskiej znalazły się również przepisy dotyczące obowiązku służby wojskowej. W art. 4 ust. 1 stwierdzono, że uzupełnianie sił zbrojnych opiera się na poborze, zaś w ust. 2 dodano, że zakres obowiązku poboru, a także zadania sił zbrojnych, uzbrojonych formacji korpusu bezpieczeństwa, korpusu ratunkowego i służb ratowniczych, ich organizację, szkolenie i obsadę personelu oraz status prawny ich członków są określone przez prawo zapewniając cywilny nadzór nad siłami zbrojnymi. Dodatkowo w ustawie konstytucyjnej ustanowiono instytucję Rady Bezpieczeństwa Narodowego, którą zgodnie z art. 9 tworzą premier i inni ministrowie wskazani przez rząd. Rada Bezpieczeństwa Narodowego w ramach swoich kompetencji określonych przez rząd, przygotowuje propozycje związane $\mathrm{z}$ bezpieczeństwem Republiki Czeskiej. Prezydent może uczestniczyć w posiedzeniach Rady Bezpieczeństwa Narodowego, a także żądać raportów z jej prac oraz omawiać wszystkie kwestie wchodzące w zakres jej kompetencji.

Z kolei w ostatnim $\mathrm{z}$ analizowanych państw - Estonii - ustawa zasadnicza z 28 czerwca 1992 r. ${ }^{67}$ zawiera dość szeroki katalog przepisów dotyczących sił zbrojnych i obronności państwa. Przede wszystkim wyodrębniono w niej rozdział zatytułowany „Obrona państwa” w całości poświęcony tym zagadnieniom. Wyraźnie wyróżnia to estońską ustawę zasadniczą na tle innych konstytucji omawianych tu państw ${ }^{68}$.

Kwestię obywatelskiego obowiązku obrony Ojczyzny unormowano w art. 124 Konstytucji Estonii, zgodnie z którym „obywatele Estonii obowiązani są brać udział w obronie państwa na podstawie i w trybie określonym w ustawie. Osoby, które z powodów religijnych lub przekonań moralnych odmawiają służby w Siłach Obrony, obowiązane są odbyć służbę zastępczą w trybie przewidzianym w ustawie".

${ }^{66}$ Uzbrojony korpus bezpieczeństwa (Ozbrojený bezpečnostní sbor) tworzą Policja, Służba Więzienna i Administracja Celna Republiki Czeskiej, zob. http://www.mvcr.cz/clanek/ozbrojeny-bezpecnostni-sbor.aspx [dostęp: 30.08.2019].

${ }^{67}$ Konstytucja Republiki Estońskiej przyjęta przez obywateli Republiki Estońskiej w referendum przeprowadzonym w dniu 28 czerwca 1992 r., thum. P. Aarne, [w:] http://biblioteka.sejm.gov.pl/wp-content/uploads/2015/10/Estonia_pol_010811.pdf [dostęp: 30.03.2019].

${ }^{68}$ Należy podkreślić, że rozdział Konstytucji RFN zatytułowany „Stan Obrony” dotyczy tylko regulacji kwestii stanu nadzwyczajnego, natomiast rozdział „Obrona państwa” w Konstytucji Estonii ma dużo szerszy zakres. 
Omawiany przepis reguluje także, że osoby odbywające służbę w Siłach Obrony i służbę zastępczą korzystają ze wszystkich konstytucyjnych praw i wolności, jeżeli ustawa $\mathrm{z}$ powodu specyfiki służby nie stanowi inaczej. Dodatkowo w art. 29 ustanowiono, że pełnienie służby wojskowej lub zastępczej stanowi wyjątek od zasady, że nikogo nie można zmusić wbrew jego woli do pracy lub służby. Natomiast art. 124 jest rozwinięciem art. 54, zgodnie z którym obowiązkiem obywatela Estonii jest wierność konstytucyjnemu ustrojowi i obrona niepodległości Estonii.

Z kolei art. 125 wprowadza zasadę neutralności politycznej sił zbrojnych, a na jego mocy osoby odbywające zasadniczą służbę wojskową nie mogą pełnić żadnej państwowej funkcji z wyboru, bądź mianowania, ani uczestniczyć w działalności jakiejkolwiek partii politycznej. Natomiast art. 63 stanowi, że członek Parlamentu (Riigikogu) jest zwolniony z obowiązku służby w Siłach Obrony na czas kadencji.

Estońska Konstytucja normuje również, że podstawy organizacyjne Sił Obrony i organizację obrony państwa określa ustawa (art. 126). Najwyższym zwierzchnikiem obrony państwa jest Prezydent Republiki, któremu jako organ doradczy służy Rada Obrony Państwa (art. 127). Na wniosek Prezydenta Riigikogu wprowadza stan wojenny, mobilizację i demobilizację oraz podejmuje decyzje o wykorzystaniu Sił Obrony do wypełnienia międzynarodowych zobowiązań Państwa Estońskiego. Prezydent posiada również kompetencje do samodzielnego wprowadzenia stanu wojennego i mobilizacji (bez zgody Parlamentu) w wypadku agresji skierowanej przeciwko Republice Estońskiej (art. 128). Ponadto Prezydent oraz Rząd Republiki mają uprawnienie do złożenia wniosku do Riigikogu o wprowadzenie stanu wyjątkowego w wypadku zaistnienia niebezpieczeństwa zagrażającego konstytucyjnemu ustrojowi państwa (art. 129). Należy też zaznaczyć, że art. 106 estońskiej ustawy zasadniczej wprowadza organicznie w zakresie dziedzin, które nie mogą być poddane głosowaniu w referendum, do których zalicza m.in. kwestię obrony państwa ${ }^{69}$.

\section{PODSUMOWANIE}

W Konstytucji RP przepisy dotyczące sił zbrojnych i obronności państwa znajdują się w różnych rozdziałach ustawy zasadniczej m.in. wśród głównych zasad ustrojowych (rozdział I), wolności, praw i obowiązków człowieka i obywatela (rozdział II), zadań władzy ustawodawczej i wykonawczej (rozdziały IV, V i VI) oraz regulacji dotyczących stanów nadzwyczajnych (rozdział XI). Tym niemniej

${ }^{69}$ Więcej na temat funkcji i zadań naczelnych organów państwa Republiki Estonii w zakresie bezpieczeństwa i obrony narodowej zob. M.A. KAmiŃsKi, Obrona Narodowa Republiki Estonii, Torun: Wydawnictwo Adam Marszałek 2018, s. 141-158. 
przepisy te są ze sobą mocno powiązane i powinny być rozpatrywane wspólnie, na co wskazuje zarówno orzecznictwo Trybunału Konstytucyjnego, jak też poglądy doktryny nauk prawnych oraz nauki o bezpieczeństwie.

Generalnie zbiór tych przepisów tworzy dość spójny i rozbudowany katalog. Tym niemniej należy jednak podkreślić brak spójności w przypadku posługiwania się przez ustawodawcę pojęciem „bezpieczeństwa”. W Konstytucji RP oprócz „bezpieczeństwa państwa” występują bowiem również pojęcia „bezpieczeństwo zewnętrzne”, „bezpieczeństwo wewnętrzne”, „bezpieczeństwo obywateli”, „,bezpieczeństwo granic”, „bezpieczeństwo ekologiczne”. Wszystkie te rodzaje bezpieczeństwa mieszczą się w pojęciu „bezpieczeństwa narodowego”, które jednak w ustawie zasadniczej nie występuje. Z całą pewnością słuszny jest więc postulat ujednolicenie podstawowych pojęć z zakresu bezpieczeństwa w Konstytucji RP jak też ustawodawstwie zwykłym.

Badania porównawcze konstytucji 8 państw członkowskich Sojuszu Północnoatlantyckiego wykazały, że możemy podzielić je na dwie grupy o „szerokich” oraz „wąskich” regulacjach prawnych w zakresie sił zbrojnych i obronności państwa. Do grupy o szerokich regulacjach konstytucyjnych możemy zaliczyć konstytucje Niemiec, Hiszpanii, Grecji, Czech i Estonii, zaś do drugiej grupy konstytucje Francji, Danii i Norwegii. Na tym tle polska ustawa zasadnicza zdecydowanie należy do grupy o szerokich regulacjach i wyróżnia się dość rozbudowanym katalogiem przepisów z tej materii, co potwierdza postawioną na wstępie artykułu hipotezę.

Najbardziej zbliżone do polskich rozwiązań wydają się konstytucje Niemiec i Hiszpanii. Natomiast zaliczająca się do tej samej grupy ustawa zasadnicza Estonii jako jedyna posiada również odrębny rozdział poświęcony obronie narodowej, zaś $\mathrm{w}$ przypadku pozostałych państw, przepisy z tej tematyki rozsiane są w różnych rozdziałach konstytucji (tak jak w Polsce).

Z kolei ustawy zasadnicze Francji, Danii i Norwegii traktują zagadnienia sił zbrojnych w dość wąskim zakresie pozostawiając uregulowania głównie ustawodawstwu zwykłemu. Szczególnie minimalistycznie traktują te zagadnienia konstytucje państw nordyckich.

Szczegółowe rozwiązania konstytucyjne można podzielić na kilka segmentów tematycznych, co obrazuje poniższa tabela:

Przeprowadzona analiza uwidoczniła też, że szerokie bądź wąskie regulacje konstytucyjne w zakresie sił zbrojnych nie zależą od modelu służby wojskowej. Wśród państw o wąskich regulacjach jest zarówno Francja posiadająca model armii zawodowej, jak też Dania i Norwegia bazująca na modelu armii poborowej. Natomiast w przypadku państw o szerokich regulacjach model armii zawodowej posiadają Niemcy, Hiszpania i Czechy, a model armii poborowej funkcjonuje w Grecji i Estonii. 


\section{Tabela 1}

Konstytucyjne regulacje w zakresie sił zbrojnych i obronności państwa w wybranych państwach członkowskich Sojuszu Północnoatlantyckiego

\begin{tabular}{|c|c|c|c|c|c|c|c|}
\hline & 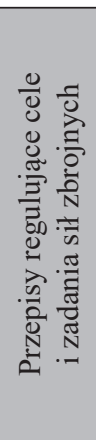 & 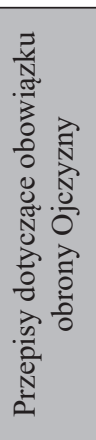 & 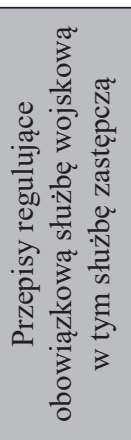 & 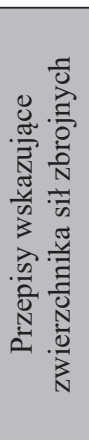 & 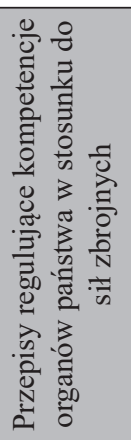 & 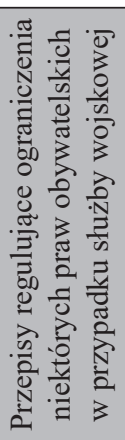 & 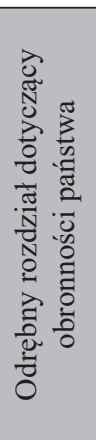 \\
\hline Polska & $\mathrm{X}$ & $X$ & $X$ & $X$ & $\mathrm{X}$ & $\mathrm{X}$ & \\
\hline Niemcy & $\mathrm{X}$ & $X$ & $X$ & $X$ & $X$ & $X$ & \\
\hline Francja & $X$ & & & $X$ & $X$ & & \\
\hline Hiszpania & $X$ & $X$ & $X$ & $\mathrm{X}$ & $\mathrm{X}$ & $X$ & \\
\hline Grecja & & $X$ & $X$ & $\mathrm{X}$ & $X$ & $X$ & \\
\hline Dania & & $\mathrm{X}$ & & $X$ & $X$ & $X$ & \\
\hline Norwegia & & $X$ & & $X$ & $\mathrm{X}$ & & \\
\hline Czechy & $\mathrm{X}$ & $\mathrm{X}$ & $\mathrm{X}$ & $X$ & $\mathrm{X}$ & $\mathrm{X}$ & \\
\hline Estonia & $\mathrm{X}$ & $\mathrm{X}$ & $\mathrm{X}$ & $\mathrm{X}$ & $\mathrm{X}$ & $\mathrm{X}$ & $\mathrm{X}$ \\
\hline
\end{tabular}

Źródło: Opracowanie własne na podstawie konstytucji analizowanych państw

\section{BIBLIOGRAFIA}

\section{ŹRÓDŁA PRAWA}

Deklaracja praw człowieka i obywatela z 26 sierpnia 1789 r., tłum. W. Skrzydło, [w:] http://biblioteka. sejm.gov.pl/wp-content/uploads/2015/10/Francja_pol_010711.pdf [dostęp: 30.03.2019].

Konstytucja Królestwa Norwegii uchwalona przez Zgromadzenie Konstytucyjne w Eidsvold 17 maja 1814 r., tłum. J. Osiński, [w:] http://biblioteka.sejm.gov.pl/wp-content/uploads/2016/02/ Norwegia_pol_010196.pdf [dostęp: 30.03.2019].

Ustawa Zasadnicza Republiki Federalnej Niemiec z 23 maja 1949 r., thum. B. Banaszak, A. Malicka, [w:] http://libr.sejm.gov.pl/tek01/txt/konst/niemcy.html [dostęp: 30.03.2019].

Konstytucja Polskiej Rzeczypospolitej Ludowej z dnia 22 lipca 1952 r., Dz. U. Nr 33, poz. 232.

Konstytucja Królestwa Danii z 5 czerwca 1953 r., thum M. Grzybowski, [w:] http://biblioteka.sejm. gov.pl/wp-content/uploads/2015/07/Dania_pol_010811.pdf [dostęp: 30.03.2019].

Konstytucja Republiki Francuskiej z 4 października 1958 r., tłum. W. Skrzydło, [w:] http://biblioteka. sejm.gov.pl/wp-content/uploads/2015/10/Francja_pol_010711.pdf [dostęp: 30.03.2019].

Konstytucja Grecji z 9 czerwca 1975 r., thum. G. Ulicka, W. Ulicki, B. Zdaniuk [i in.], [w:] http:// biblioteka.sejm.gov.pl/wp-content/uploads/2015/10/Grecja_pol_010711.pdf [dostęp: 30.03.2019]. 
Konstytucja Hiszpanii z 27 grudnia 1978 r., thum. T. Mołdawa, [w:] http://biblioteka.sejm.gov.pl/ wp-content/uploads/2015/10/Hiszpania_pol_300612.pdf [dostęp: 30.03.2019].

Konstytucja Republiki Estońskiej przyjęta przez obywateli Republiki Estońskiej w referendum przeprowadzonym w dniu 28 czerwca 1992 r., thum. P. Aarne, [w:] http://biblioteka.sejm.gov.pl/ wp-content/uploads/2015/10/Estonia_pol_010811.pdf [dostęp: 30.03.2019].

Konstytucja Republiki Czeskiej z 16 grudnia 1992 r., tłum. M. Kruk-Jarosz, [w:] http://biblioteka. sejm.gov.pl/wp-content/uploads/2015/07/Czechy_pol_010811.pdf [dostęp: 30.03.2019].

Konstytucja Rzeczypospolitej Polskiej z dnia 2 kwietnia 1997 r., Dz. U. Nr 78, poz. 483 z późn. zm.

Constitutional Act of Law No. 110/1998 Coll., of April, 22nd 1998, on Security of the Czech Republic, as amendmended by No. 300/2000 Coll., [w:] http://www.psp.cz/en/docs/laws/1998/110. html [dostęp: 30.03.2019].

Ustawa Konstytucyjna Królestwa Polskiego z dnia 27 listopada 1815 r. [w:] Konstytucje w Polsce: 1791-1990, wyb. i oprac. T. Kołodziejczyk, M. Pomianowska, Warszawa: Wydawnictwo Przemiany 1990 , s. 48-57.

Ustawa Konstytucyjna Księstwa Warszawskiego z dnia 22 lipca 1807 r., [w:] Konstytucje w Polsce: 1791-1990, wyb. i oprac. T. Kołodziejczyk, M. Pomianowska, Warszawa: Wydawnictwo Przemiany 1990 , s. 37-43.

Ustawa Rządowa z 3 maja 1791 r., [w:] Konstytucje w Polsce: 1791-1990, wyb. i oprac. T. Kołodziejczyk, M. Pomianowska, Warszawa: Wydawnictwo Przemiany 1990, s. 13-18.

Ustawa z dnia 17 marca 1921 r. Konstytucja Rzeczypospolitej Polskiej, Dz. U. Nr 44, poz. 267 i Nr 52, poz. 334.

Ustawa konstytucyjna z dnia 23 kwietnia 1935 r., Dz. U. Nr 30, poz. 227.

Ustawa z dnia 21 listopada 1967 r. o powszechnym obowiązku obrony Rzeczypospolitej Polskiej, Dz. U. z 2019 r., poz. 1541.

Ustawa z dnia 14 grudnia 1995 r. o stanie wojennym oraz o kompetencjach Naczelnego Dowódcy Sił Zbrojnych i zasadach jego podległości konstytucyjnym organom Rzeczypospolitej Polskiej, Dz. U. z 2017 r., poz. 1932.

Ustawa z dnia 14 grudnia 1995 r. o urzędzie Ministra Obrony Narodowej, Dz. U. z 2019 r., poz. 196. Ustawa z dnia 18 kwietnia 2002 r. o stanie klęski żywiołowej, Dz. U. z 2017 r., poz. 1897.

Ustawa z dnia 21 czerwca 2002 r. o stanie wyjątkowym, Dz. U. z 2017 r., poz. 1928.

Ustawa z dnia 28 listopada 2003 r. o służbie zastępczej, Dz. U. z 2018 r., poz. 885.

Ustawa z dnia 2 kwietnia 2009 r. o obywatelstwie polskim, Dz. U. z 2018 r., poz. 1829.

Rozporządzanie Ministra Nauki i Szkolnictwa Wyższego z dnia 20 września 2018 r. w sprawie dziedzin nauki i dyscyplin naukowych oraz dyscyplin artystycznych, Dz. U. poz. 1818.

Uchwała Centralnej Komisji do Spraw Stopni i Tytułów z dnia 28 stycznia 2011 r. zmieniająca uchwałę w sprawie określenia dziedzin nauki i dziedzin sztuki oraz dyscyplin naukowych i artystycznych, M. P. Nr 14, poz. 149.

\section{ORZECZNICTWO}

Wyrok Trybunału Konstytucyjnego z dnia 16 lutego 1999 r., sygn. akt SK 11/98, Dz. U. Nr 20, poz. 182. Wyrok Trybunału Konstytucyjnego z dnia 3 lipca 2001 r., sygn. akt K 3/01, Dz. U. Nr 69, poz. 725. Wyrok Trybunału Konstytucyjnego z dnia 10 kwietnia 2002 r., sygn. akt K 26/00, Dz. U. Nr 56, poz. 517.

Wyrok Trybunału Konstytucyjnego z dnia 11 lutego 2003 r., sygn. akt P 12/02, Dz. U. Nr 35, poz. 312. 
Wyrok Trybunału Konstytucyjnego z dnia 25 listopada 2003 r., sygn. akt K 37/02, M. P. Nr 56, poz. 877.

\section{LITERATURA}

Balcerowicz Bolesław: Siły zbrojne w stanie pokoju, kryzysu, wojny, Warszawa: Wydawnictwo Naukowe Scholar 2010.

Chojnowski Lech: Bezpieczeństwo narodowe. Studium teoretyczne, Słupsk: Wydawnictwo Naukowe Akademii Pomorskiej 2016.

Снomoncik Sławomir: Ustawa o służbie wojskowej żołnierzy zawodowych. Komentarz, Toruń: Wydawnictwo Adam Marszałek 2019.

DziaŁocha Kazimierz: Komentarz do art. 85, [w:] Konstytucja Rzeczypospolitej Polskiej. Komentarz. Tom I, red. L. Garlicki, M. Zubik, Warszawa: Wydawnictwo Sejmowe 2016, s. 989-1000.

FlorCZAK-WąTor Monika: Komentarz do art. 5, [w:] Konstytucja RP. Tom I. Komentarz do art. 1-86, red. M. Safian, L. Bosek, Warszawa: Wydawnictwo C.H. Beck, 2016, s. 282-289.

GrZeBYK Patrycja: Komentarz do art. 26, [w:] Konstytucja RP. Tom I. Komentarz do art. 1-86, red. M. Safian, L. Bosek, Warszawa: Wydawnictwo C.H. Beck 2016, s. 1888-1897.

KamiŃski Mariusz Antoni: Obrona Narodowa Republiki Estonii, Toruń: Wydawnictwo Adam Marszałek 2018.

KAMiŃSKi Mariusz A.: Profesjonalizacja i modernizacja techniczna Sił Zbrojnych RP w pracach ustawodawczych (2008-2010), [w:] Przestępczość w XXI wieku - zapobieganie i zwalczanie. Problemy prawno-kryminologiczne, red. E. Pływaczewski, W. Filipkowski, Z. Rau, Warszawa: Wolters Kluwer 2015, s. 308-323.

KAMIŃSKi Mariusz A.: Status prawny i praktyka funkcjonowania podkomisji w Sejmie RP, Przegląd Sejmowy 4 (2018), s. 19-37.

KAMIŃsKi Mariusz A.: Uwarunkowania prawno-organizacyjne współpracy Policji i Sił Zbrojnych RP w działaniach kontrterrorystycznych w budynkach użyteczności publicznej, [w:] Bezpieczeństwo antyterrorystyczne budynków użyteczności publiczne. Metody i narzędzia zamachów vs działania antyterrorystyczne i kontretrrorystyczne, red. B. Wiśniewska-Paź, M. Szostak, J. Stelmach, Toruń: Wydawnictwo Adam Marszałek 2018, s 137-155.

KitLER Waldemar: Bezpieczeństwo narodowe RP: podstawowe kategorie, uwarunkowania, system, Warszawa: Wydawnictwo Akademii Obrony Narodowej 2011.

KitLER Waldemar: Organizacja bezpieczeństwa narodowego RP. Aspekty ustrojowe, prawno-administracyjne i systemowe, Toruń: Wydawnictwo Adam Marszałek 2018.

KITLER Waldemar: Rola sił zbrojnych w państwie, [w:] Prawo wojskowe, red. W. Kitler, D. Nowak, M. Stepnowska, Warszawa: Woltes Kluwer 2017, s. 27-45.

Kolodziejczak Malwina: The Commander-in-Chief in Command and Control System of the Republic of Poland, Journal on Baltic Security 2 (2016), s. 89-101.

KozIEJ Stanisław: Bezpieczeństwo: istota, podstawowe kategorie i historyczna ewolucja, Bezpieczeństwo Narodowe 18 (2018), s. 19-39.

MöLDER Holger: The Development of Military Cultures, [w:] Apprenticeship, Partnership, Membership: Twenty Years of Defence Development in the Baltic States, red. T. Lawrence, T. Jermalavičius, Tallinn: International Center for Defence Studies 2013, s. 85-121.

PACEK Bogusław: Udział Sił Zbrojnych RP w bezpieczeństwie wewnętrznym państwa, Warszawa: Wydawnictwo Akademii Obrony Narodowej 2013.

SARneCKI Paweł: Komentarz do art. 26, [w:] Konstytucja Rzeczypospolitej Polskiej. Komentarz. Tom I, red. L. Garlicki, M. Zubik, Warszawa: Wydawnictwo Sejmowe 2016, s. 631-637. 
Słownik terminów z zakresu bezpieczeństwa narodowego, red. J. Kaczmarek, W. Łepkowski, B. Zdrodowski, Warszawa: Wydawnictwo Akademii Obrony Narodowej 2008.

SoboLewski Grzegorz: Siły Zbrojne RP w zarządzaniu kryzysowym. Aspekt narodowy i międzynarodowy, Warszawa: Wydawnictwo Akademii Obrony Narodowej 2013.

StrzęPeK Kamil: Znaczenie prawne wstępu do Konstytucji RP z 1997 roku, Warszawa: Wydawnictwo Sejmowe 2003.

WoŁPIUK Waldemar: Siły Zbrojne w regulacjach Konstytucji RP, Warszawa: Wydawnictwo Scholar 1998.

ZDRODowsKi Bogdan: Rozważania o bezpieczeństwie państwa, [w:] Od sztuki wojennej do bezpieczeństwa narodowego, red. W. Kitler, Warszawa: Wydawnictwo Akademii Obrony Narodowej 2017, s. od-do.

\section{PRAWNOUSTROJOWY STATUS SIŁ ZBROJNYCH W KONSTYTUCJI RZECZYPOSPOLITEJ POLSKIEJ}

\section{Streszczenie}

Artykuł prezentuje wyniki badań w zakresie prawnoustrojowego statusu Sił Zbrojnych w Konstytucji RP. Analizie została poddana rola Sił Zbrojnych RP w realizacji głównych celów państwa polskiego i ich relacje do innych zasad ustrojowych oraz obywatelskiego obowiązku obrony Ojczyzny. Ponadto omówione zostały kompetencje naczelnych organów państwa w aspekcie obronności i bezpieczeństwa oraz cywilnej i demokratycznej kontroli nad Siłami Zbrojnymi, a także zasady pełnienia służby wojskowej w kontekście praw i wolności obywatelskich. Następnie polskie rozwiązania konstytucyjne zostały poddane analizie prawnoporównawczej z przepisami konstytucji wybranych państw członkowskich Sojuszu Północnoatlantyckiego - Niemiec, Francji, Hiszpanii, Grecji, Danii, Norwegii, Estonii i Czech.

Słowa kluczowe: Siły Zbrojne; Wojsko Polskie; prawo wojskowe; bezpieczeństwo narodowe; obrona narodowa; siły zbrojne w konstytucji

\section{THE LEGAL STATUS OF THE POLISH ARMED FORCES IN THE CONSTITUTION OF THE REPUBLIC OF POLAND}

\section{Sum mary}

The article presents the results of research of the legal status of the Polish Armed Forces in the Constitution of the Republic of Poland. The key problems include the role of the Armed Forces in the implementation of the main goals of the Polish state and their relations to other constitutional principles and the duty to defend the Homeland. The article also presents the competences of the executive and legislative authorities in the aspect of defence and security as well as civil and democratic control over the Armed Forces. Polish legal solutions were compared with the constitutions of NATO member states - Germany, France, Spain, Greece, Denmark, Norway, Estonia and the Czech Republic.

Key words: Armed Forces; Polish Army; military law; national security; national defence; armed forces in the constitution 